\title{
Threshold Regression Model for Taylor Rule: The Case of Turkey
}

\author{
PINAR DENIZ* \\ Marmara University \\ THANASIS STENGOS ${ }^{\dagger}$ \\ University of Guelph \\ EGE YAZGAN \\ Istanbul Bilgi University
}

\begin{abstract}
This paper employs the structural threshold approach of Kourtellos et al. (2016) to examine various specifications of the Taylor rule model. Contrary to the previous work on the Taylor rule, this methodology allows for endogeneity of the threshold variable in addition to the right-hand-side variables suggesting a fully comprehensive flexible framework that does not rely on restrictive linearity and/or exogeneity assumptions. In order to examine the model, Turkey is selected as an inflation targeting developing economy, since its central bank (the Central Bank of Turkey) as argued by Dincer and Eichengreen (2014) has been one of the fastest improving central banks in terms of its transparency score. We will use monthly data for the period of 2004-2018 that includes a number of historical episodes such as the global financial crisis as well as various internal political developments that may have had an impact on the fluctuations of the relevant macroeconomic variables as well as on the functional form of the inflation targeting Taylor rule specification. Empirical findings highlight the different reactions of the central bank in determining policy rate under different regimes.
\end{abstract}

Keywords: Nonlinearities, Taylor rule, Threshold regression models

JEL Classifications: C26, E52, E58

\footnotetext{
*pinar.deniz@marmara.edu.tr, Marmara niversitesi Gztepe YerleÅkesi, 34722 Kadky, stanbul

$\dagger$ tstengos@uoguelph.ca, 50 Stone Road East Guelph, Ontario, Canada N1G 2W1

‡ege.yazgan@bilgi.edu.tr, Kazm Karabekir Cad. No: 2/13, 34060, Eypsultan, stanbul

(C) 2020 Pinar Deniz, Thanasis Stengos, and Ege Yazgan. Licenced under the Creative Commons Attribution-Noncommercial 3.0 Licence (http://creativecommons.org/licenses/by-nc/3.0/). Available at http://rofea.org.
} 


\section{Introduction}

The Turkish economy has had a long history of high inflation, even reaching levels of over a hundred percent, combined with successive periods of economic crises in 1979, 1994, 1997 and 2001. After the decades of high inflation, Central Bank of the Republic Turkey (CBRT) was officially granted its independence following the amendment of the Central Bank Law in 2001 and started to implement implicit inflation targeting (IT) policies. Following a successful disinflation effort which managed to bring down the inflation rate to single digits, IT was explicitly adopted as the main target policy. As a result CBRT gained credibility and found itself among the top central banks in terms of its rapid increase in the transparency index achieved. Within the group of over 120 central banks CBRT's transparency score rose from 3.2 in 1998 to 5.5 in 2010 (Dincer and Eichengreen, 2014). The success of this disinflation effort ${ }^{1}$ led researchers to estimate different Taylor rule models for Turkey (Us, 2007; Yazgan and Yilmazkuday, 2007; Çağlayan and Astar, 2010; Aklan and Nargelecekenler, 2008; Civcir and Akçağlayan, 2010; Khakimov et al., 2010; Erdem and Kayhan, 2011; Güney, 2016). These studies provided different results for the estimated parameters as they consider different periods, versions of the rule and different methodologies.

Following the great financial crisis 2009, the monetary policy of CBRT has been gradually redesigned and a macroprudential policy approach has become more and more dominant (Kara, 2012 , 2016). This redesign in the monetary policy approach has raised some concerns regarding the loss of the main objective of maintaining price stability. Gürkaynak et al. (2015) stated that while CBRT was a strong inflation targeter early in 2000's, it has began to pay less attention to inflation after 2009. They also provided empirical evidence to their claim by detecting a change in the estimated policy rule coefficient at that date. From the institutional perspective Ozel, 2012 indicated a deterioration in the independence of Turkish regulatory agencies in general, including the CBRT, even though they were regarded as a model for a number of countries at the begining of 2000's. Similarly Demiralp and Demiralp (2019) pointed out that CBRT has currently been experiencing an erosion in its independence. They showed that political intervention, as captured by political commentaries favoring a drop in interest rates, is as influential as traditional variables in the Taylor rule.

These policy changes and concerns of political interventions indicates the importance of introducing non-linearities and regime changes in modeling Taylor rule targeting for Turkey. This topic has been recently analyzed together with some other emerging market countries by Caporale et al. (2018) via a threshold model using the inflation as a threshold variable. In this paper, we also analyze the Taylor rule targeting of Turkey via threshold models allowing however for the threshold variable and the regressors to be endogenous. In the literature of nonlinear regression models, threshold regression offers a convenient and parsimonious way to charac-

\footnotetext{
${ }^{1}$ See Ersel and Özatay (2008) and Benlialper and Cömert (2015)
} 


\section{DENIZ, STENGOS, YAZGAN Taylor Rule Model for Turkey}

terize nonlinearities without running into curse of dimensionality issues that plague alternative nonparametric and semiparametric approaches. These models imply that below and under the estimated threshold parameter, the slope parameters differ and imply regime specific marginal responses. Initial studies based on the work of Hansen (2000) and Caner and Hansen (2004), even allowing for endogenous regressors, assume that the threshold variable itself is exogenous. The structural threshold models by Kourtellos et al. (2016) provides a generalization that allows for the endogeneity for the threshold variable and also regime-specific heteroscedasticity. In this paper we will follow their approach as our estimation strategy, since the threshold variable may be in itself an important determinant that cannot be separated in an ad hoc manner from the other potentially endogenous regressors.

The rest of the study is organized as follows. Section 2 explains the model, data and methodology. Section 3 presents the empirical findings, while the last section concludes the paper. In the appendix we collect a variety of additional Taylor rule specifications that were estimated in addition to the ones reported in the main text ${ }^{2}$. These different specifications confirm the main features of the models presented in the main body of the paper.

\section{Model and methodology}

The Taylor rule suggests a basic monetary policy rule ${ }^{3}$ for central banks such that inflation and real output deviations from their target levels would be determining the short-term interest rate target. Following this basic rule, several different versions are used in the literature taking into account open economy requirements and country specifications. We consider two different specification for the Taylor rule.

\subsection{Model I}

This first model is a basic Taylor rule augmented by exchange rate. The standard Taylor rule (Taylor, 1993) observes a policy rule for Federal Reserve suggesting that inflation gap and output gap are the determinants of the federal funds rate. Several papers considered the incorporation of exchange rate as an additional variable into the policy rule (see, among others, Taylor (2001) and Mohanty and Klau (2005)). Many studies of Turkish monetary policy high-

\footnotetext{
${ }^{2}$ In the literature, there are many criticisms against different specifications. Hamilton (2018) criticizes HP filtering technique for calculations of gap. Fernandez et al. (2010) suggests that unemployment rate is more useful than detrended output in the monetary policy models. Orphanides (2003) argues that concepts such as the natural rate of interest and potential output are known to be notoriously unreliable as policy indicators. Yellen (2005) criticizes constant natural (or neutral) real interest rate. Considering these criticisms, we run several Taylor rule estimations using different specifications for relevant variables. We do not document all the results to conserve some space, however, the complete results can be provided upon request.

${ }^{3}$ Taylor (1993) provides a policy rule for Federal Reserve suggesting that inflation $(\pi)$ above a target of 2 percent and percentage deviation of real GDP from its trend $(y)$ affect federal funds rate $(r)$ by 0.5 , i.e., $r=\pi+0.5 y+0.5(\pi-2)+2$.
} 
light the importance of the inclusion of exchange rate in the policy rule considering the fragility of economy to exchange rate shocks (Us, 2007; Civcir and Akçağlayan, 2010; Erdem and Kayhan, 2011). Moreover, Turkey was found as the only country whose reaction function has a significant response to exchange rate changes among the 5 emerging markets considered by Caporale et al. (2018, pp.312). Following this literature, the first estimated Taylor rule in this paper also includes an exchange rate variable in addition to inflation gap and output gap. Froyen and Guender (2018) strongly suggest the use of real exchange rate in a Taylor rule specification and following this suggestion, we will use the real exchange rate rather than the nominal one.

The model employs policy rate $\left(i_{t}\right)$ as a function of inflation gap, which is the difference between realized inflation $\left(\pi_{t}\right)$ and the inflation target set by the central bank $\left(\pi_{t}^{T}\right)$, output gap $\left(\tilde{y}_{t}\right)$, which is calculated as HP filtered output, and the real effective exchange rate $\left(\right.$ rer $\left._{t}\right)$.

$$
i_{t}=\beta_{0}+\beta_{1}\left(\pi_{t}-\pi_{t}^{T}\right)+\beta_{2} \tilde{y}_{t}+\beta_{3} \text { rer }_{t}
$$

\subsection{Model II}

The second model is selected based on CBRT's own approach to be country specific, as outlined in inflation reports of CBRT (CBRT, 2018). This model takes the natural real interest rate into account:

$$
r_{t}=r_{t-1}^{*}+\rho_{r}\left(r_{t-1}-r_{t-1}^{*}\right)+\left(1-\rho_{r}\right)\left(\theta_{\pi} E_{t}\left(\pi_{t+1}-\pi_{t}^{T}\right)+\theta_{y} \tilde{y}_{t}\right)+u_{t}
$$

where $\tilde{y}_{t}$ is the output gap using HP filter, $r_{t}$ is the interest rate minus the average inflation rate and $r^{*}$ is the natural (neutral) real interest rate.

\subsection{Methodology}

In this study, the two Taylor rule models outlined above are examined using a threshold regression methodology, an approach that relies on a parsimonious modeling of possible nonlinearities that avoids the curse of dimensionality issue that plagues alternative nonparametric methodologies. Threshold regression models have been used extensively in applied work in the last twenty years. In the first generation of threshold models, Hansen (2000) developed a useful asymptotic distribution theory for both the threshold parameter estimate and the regression slope coefficients under the assumption that the threshold effect becomes smaller as the sample increases, while Caner and Hansen (2004) allowed for endogenous regressors, under an exogenous threshold variable framework. In the second generation of threshold models Kourtellos et al. (2016) allow for an endogenous threshold variable. The main strategy here was to exploit the intuition obtained from the limited dependent variable literature, and to relate the problem of having an endogenous threshold variable with the analogous problem of having an endogenous dummy variable or sample selection in the limited dependent variable framework. However, there is one 


\section{DENIZ, STENGOS, YAZGAN Taylor Rule Model for Turkey}

important difference. While in sample selection models, we observe the assignment of observations into regimes but the (threshold) variable that drives this assignment is taken to be latent, here, it is the opposite here as we do not know which observations belong to which regime (we do not know the threshold value), but we can observe the threshold variable. To put it differently, while endogenous dummy models treat the threshold variable as unobserved and the sample split as observed (dummy), here one treats the sample split value as an unknown to be estimated. Just as in the limited dependent variable framework, consistent estimation of slope parameters under normality requires the inclusion of a set of inverse Mills ratio bias correction terms, implying that the slope parameter estimates of the threshold regression by Hansen (2000) and Caner and Hansen (2004) will be inconsistent in the endogenous threshold variable case due to the omission of the inverse Mills ratio bias correction terms.

As there are many potential endogenous threshold variable candidates we select the one that best fits the data using a GMM J-statistic criterion to identify the best threshold model out of the pool of threshold variable candidates. Once the threshold variable is selected then we will adopt both a two stage least squares (2SLS) and GMM estimation approach for the estimation of slope parameters and we will also provide asymptotically valid confidence intervals for the threshold parameter. We will proceed as follows. We first test the null hypothesis of linearity against the alternative of a nonlinear Taylor rule model using the LM-test of Hansen (2000) for all possible threshold variable candidates and select the one with the best fit according to the J-statistic. We then estimate the threshold Taylor rule models, by applying the Kourtellos et al. (2016) structural threshold regression (STR) estimation tests using both two-stages least squares and GMM methodology.

\section{Empirical Findings}

\subsection{Data}

We employ monthly data for the period of 2004-2018 for Turkey. The existence of a "plethora" of interest rates employed by CBRT (see Figure 1) requires a choice on the appropriate policy rate. We use official policy rates, i.e., overnight rate for the period of January 2004 - 2010 April, one-week repo for the period of May 2010 - December 2013 and average funding rate of CBRT $^{4}$ for the period of January $2014-$ June $2018 .{ }^{5}$

Inflation is used as the annual (\%) change of CPI. Inflation target is the official target of CBRT. Output is seasonally adjusted industrial production index. Output gap is calculated by taking HP filter of logarithmic output. Real effective exchange rate (RER) is CPI 2003 based

\footnotetext{
${ }^{4}$ This is the weighted average cost of outstanding funding by the CBRT via Interbank Money Market (overnight lending facility) and Open Market Operations (BIST repo, primary dealer repo, one-week repo via quantity auction, one-week repo via traditional auction and one-month repo, see Küçük et al. (2016)

${ }^{5}$ Alp et al. (2012) and Gürkaynak et al. (2015), both use TRlibor arguing that it is a better predictor as a policy rate.
} 
Review of Economic Analysis 12 (2020) 167-202

Figure 1: Policy rates (\%)

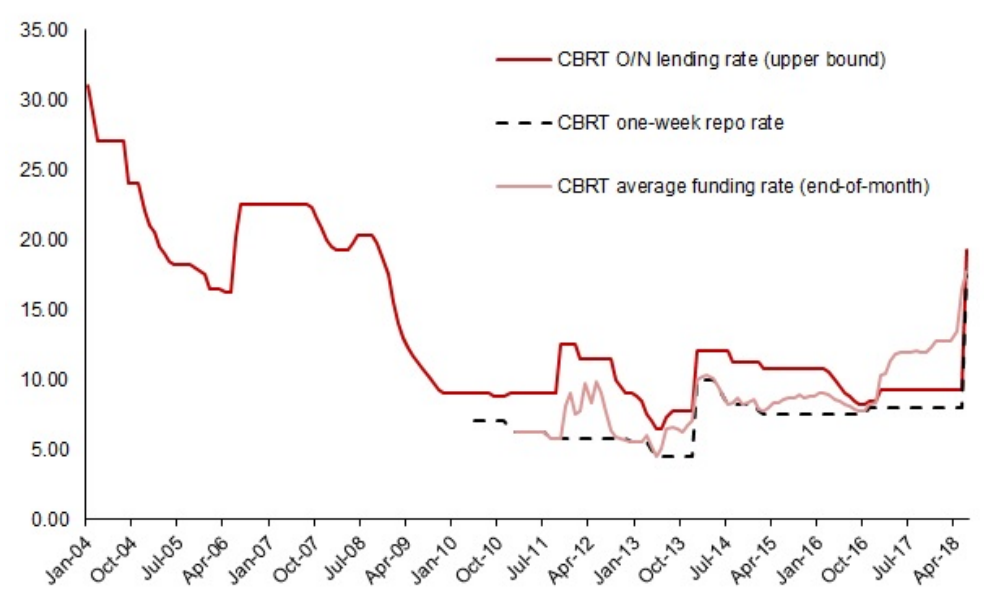

and is in logarithmic form. A rise in RER refers to appreciation. ${ }^{6}$ Table 1 presents descriptive statistics.

Table 1: Descriptive statistics

\begin{tabular}{lcccc}
\hline Variables & Mean & Std Dev & Max & Min \\
\hline Interest rate & 0.1299 & 0.0681 & 0.3100 & 0.0500 \\
Inflation rate & 0.0874 & 0.0199 & 0.1600 & 0.0400 \\
Inflation gap & 0.0235 & 0.0220 & 0.0781 & -0.0240 \\
Output gap & 0.0003 & 0.0415 & 0.0900 & -0.1500 \\
RER & 4.6697 & 0.1031 & 4.8514 & 4.3442 \\
\hline \hline
\end{tabular}

Table 2 provides Phillips and Perron (1988) and Lee and Strazicich (2003) unit root test results. The latter one allows for breaks with unknown dates. Inflation gap, output gap and real exchange rate are observed to be stationary rejecting the null hypothesis of unit root with break. However, the interest rate produces an ambiguous result with either test. There are several studies observing an ambiguity regarding the (non)stationarity property of interest rates but end up using them in levels according to theoretical arguments Clarida et al. (2000); Martin and Milas (2004, 2013); Castro (2011); Caporale et al. (2018).

${ }^{6}$ CBRT defines real effective exchange rate, which is calculated by the weighted averages of foreign currencies according to their trade ratio, using this formula: $P /\left(P^{*} X R\right)$, where $P$ and $P^{*}$ are domestic and foreign prices, respectively. 
DENIZ, STENGOS, YAZGAN Taylor Rule Model for Turkey

Table 2: Unit Root Tests

\begin{tabular}{l|cc|cc}
\hline & \multicolumn{2}{|c|}{ Phillips-Perron Test } & \multicolumn{2}{c}{ Lee-Strazizich Test } \\
Variables & $\mathrm{C}$ & $\mathrm{C}-\mathrm{T}$ & LM-Stat & Break date \\
\hline Interest rate & $-2.6030^{*}$ & -0.7824 & -2.9339 & $2014 \mathrm{M} 08$ \\
Inflation gap & -1.8450 & -0.7889 & $-4.3916^{* *}$ & $2008 \mathrm{M} 09$ \\
Output gap & $-4.7449 * * *$ & $-4.7317 * * *$ & $-4.3922^{* *}$ & $2008 \mathrm{M} 09$ \\
RER & -0.5711 & -2.0608 & $-4.2337 * *$ & $2008 \mathrm{M} 09$ \\
\hline \hline
\end{tabular}

Note: The values above are test statistics. The null hypothesis for Phillips-Perron and Lee-Strazizich tests are existence of unit root (with break in the latter one). $*, * *, * * *$ denote significance at $10 \%, 5 \%$ and $1 \%$ significance levels. For Lee-Strazizich test, the critical values for RER are $-4.7833,-4.2337$ and -3.9588 ; for the other variables are $4.7266,-4.1707$ and -3.8877 at $1 \%, 5 \%$ and $10 \%$ significance levels, successively. For Phillips-Perron test, the critical values are -2.5757 , -2.8781 and -3.4683 for constant case; $-3.1421,-3.4360$ and -4.0119 for constant and trend case, successively. C and C-T refer to constant and constant\&trend cases.

\subsection{Structural Threshold Taylor Rule model I}

In this first model, nominal interest rate is used in levels form and is regressed on inflation gap, output gap and real effective exchange rate using each variable as a candidate threshold variable. $q_{t}$ is defined as the threshold variable and $\gamma$ is the threshold parameter. Threshold variable lower/higher than the estimate for the threshold parameter denotes low regime (L) periods/high regime $(\mathrm{H})$ periods.

$$
\begin{aligned}
i_{t}=I\left(q_{t} \leq \gamma\right)\left(\beta_{0}^{L}+\beta_{1}^{L}\left(\pi_{t}-\pi_{t}^{T}\right)+\beta_{2}^{L} \tilde{y}_{t}+\beta_{3}^{L} r e r_{t}\right. \\
+I\left(q_{t}>\gamma\right)\left(\beta_{0}^{H}+\beta_{1}^{H}\left(\pi_{t}-\pi_{t}^{T}\right)+\beta_{2}^{H} \tilde{y}_{t}+\beta_{3}^{H} r e r_{t}\right)+u_{t} .
\end{aligned}
$$

Hansen (2000) LM-test in Table 3 shows that regressions with all candidate threshold variables reject the null hypothesis of linearity for model I. The Structural Threshold Taylor Rule (STR) model using GMM estimation shows that regression with the threshold variable inflation gap best fits as the $\mathbf{J}$ statistic is the lowest. However, the threshold estimate is observed to be insignificant which results in ambiguity in terms of selecting the best fitted model. There are two models with significant threshold parameters, RER and interest rate. Among these two candidates, RER has the smallest J-statistics. Hence, in Table 4, test results for the model with the threshold variable RER are provided for Hansen, STR-GMM and STR-2SLS ${ }^{7}$.

The test results reflects that in the low regime period, when RER is lower than the estimated threshold level, inflation gap and RER variables are found to be significant with negative coefficients. Keeping in mind that a rise in RER refers to an appreciation, the low regime period refers to the relatively depreciated currency period and the negative coefficient of RER suggests that

\footnotetext{
${ }^{7}$ Test results for the models with other threshold candidates are available in the appendix
} 
Review of Economic Analysis 12 (2020) 167-202

Table 3: Threshold estimates for Model 1

\begin{tabular}{l|cc|cc|c}
\hline $\begin{array}{l}\text { Threshold } \\
\text { Candidates }\end{array}$ & \multicolumn{2}{|c|}{ Hansen Test } & \multicolumn{2}{c|}{ GMM } & 2SLS \\
LM-test & Threshold & J-stat & Threshold & Threshold \\
\hline Inflation gap & 48.2661 & 0.0039 & 4.5242 & -0.0017 & 0.0039 \\
& $(0.0000)$ & {$[-0.0001,0.0070]$} & & {$[-0.0151,0.062]$} & {$[-0.0151,0.062]$} \\
Output gap & 36.7058 & 0.0112 & 22.5194 & 0.0000 & 0.0100 \\
& $(0.0000)$ & {$[0.0056,0.0249]$} & & {$[-0.05,0.05]$} & {$[-0.05,0.05]$} \\
RER & 32.2128 & 4.6619 & \multirow{2}{*}{8.5986} & 4.6687 & 4.7005 \\
& $(0.0000)$ & {$[4.6283,4.7101]$} & & {$[4.5096,4.7878]$} & {$[4.5096,4.7878]$} \\
Interest rate & 115.8041 & 0.1550 & 25.9689 & 0.1400 & 0.1400 \\
& $(0.0000)$ & {$[0.1350,0.1550]$} & & {$[0.06,0.23]$} & {$[0.06,0.23]$} \\
\hline \hline
\end{tabular}

Note: Apart from LM-test and J statistics, values above are threshold estimates. Values in brackets are confidence intervals in 95\%. Values in paranthesis for LM-test are bootstrap p-values.

a depreciation in the currency raises interest rates in this period. As will be discussed below, since depreciations not only induce serious cost inflation in Turkey but also cause inflationary expectations to become more pessimistic, CBRT is expected to have tendency to favor the appreciation. As an emerging market country raising interest rates may help to attract capital flows, hence results in appreciation which is also helpful for controlling prices. On the other hand, the inflation gap is observed to have a negative effect on interest rate contrary to theory. Hence, we may argue that when the depreciation is over the threshold, concerns on currency dominate monetary policy over inflation targeting and we observe an opposite sign on the inflation gap variable. However, in the high regime period, that is when RER is above the estimated threshold level for RER (appreciated currency), the inflation gap becomes the sole significant variable with the expected sign. In this period, there is no need for CBRT to worry about depreciation for its adverse effect on inflation so it can use its interest rate policy to dampen the domestic demand to fight against inflation.

\subsection{Structural Threshold Taylor Rule model II}

In this model, the natural real interest rate $\left(r_{t}^{*}\right)$ is estimated using Kalman filter based on Öğ̈̈nç and Batmaz (2011). ${ }^{8}$ In our model, expected inflation is the expected end of year inflation and real exchange rate is also added to the original model in equation 2 considering the importance of exchange rate to a developing open economy.

$$
\begin{aligned}
r_{t}-r_{t-1}^{*}=I\left(q_{t}\right. & \leq \gamma)\left(\beta_{0}^{L}+\beta_{1}^{L}\left(r_{t-1}-r_{t-1}^{*}\right)+\beta_{2}^{L}\left(E_{t} \pi_{\text {end }}-\pi_{t}^{T}\right)+\beta_{3}^{L} \tilde{y}_{t}+\beta_{4}^{L} r e r_{t}\right) \\
& +I\left(q_{t}>\gamma\right)\left(\beta_{0}^{H}+\beta_{1}^{H}\left(r_{t-1}-r_{t-1}^{*}\right)+\beta_{2}^{H}\left(E_{t} \pi_{\text {end }}-\pi_{t}^{T}\right)+\beta_{3}^{H} \tilde{y}_{t}+\beta_{4}^{H} \text { rer }_{t}\right)+u_{t}
\end{aligned}
$$

\footnotetext{
${ }^{8}$ They employ two alternative specifications for natural real interest rates for the period of 1989-2005. The first model assumes a simple random walk specification for natural interest rate and the second model related natural rate with a trend growth rate and risk premium. Kara et al. (2007) also make a similar proposition to the first model in their output gap model estimation. For simplicity, we employ the first model of Öğünç and Batmaz (2011)
} 
Table 4: Threshold Test Results for Model 1

\begin{tabular}{|c|c|c|c|}
\hline Variables & Hansen test & GMM & 2SLS \\
\hline Regime 1 & $R E R_{t}<\hat{\gamma}_{r e r}$ & $R E R_{t}<\hat{\gamma}_{\text {rer }}$ & $R E R_{t}<\hat{\gamma}_{\text {rer }}$ \\
\hline \multirow[t]{2}{*}{ Constant } & $2.1800 * * *$ & $3.8181 * *$ & -0.3148 \\
\hline & $(0.5137)$ & (1.6786) & $(0.8098)$ \\
\hline \multirow[t]{2}{*}{ Inflation gap } & $-1.3848 * * *$ & $-2.1986 * * *$ & $-1.1553 * * *$ \\
\hline & $(0.3128)$ & $(0.3555)$ & $(0.3415)$ \\
\hline \multirow[t]{2}{*}{ Output gap } & -0.2996 & -0.2348 & $-0.2519 *$ \\
\hline & $(0.2292)$ & $(0.227)$ & $(0.142)$ \\
\hline \multirow[t]{2}{*}{ RER } & $-0.4422 * * *$ & $-0.8306^{*}$ & 0.2189 \\
\hline & $(0.1111)$ & $(0.4785)$ & $(0.2276)$ \\
\hline Regime 2 & $R E R_{t}>\hat{\gamma}_{r e r}$ & $R E R_{t}>\hat{\gamma}_{r e r}$ & $R E R_{t}>\hat{\gamma}_{r e r}$ \\
\hline \multirow[t]{2}{*}{ Constant } & 0.225 & 1.4425 & -2.1362 \\
\hline & $(0.617)$ & $(3.035)$ & $(1.3057)$ \\
\hline \multirow[t]{2}{*}{ Inflation gap } & $0.7483 * * *$ & $1.0198 * * *$ & $1.1144 * * *$ \\
\hline & $(0.2334)$ & $(0.2368)$ & $(0.1916)$ \\
\hline \multirow[t]{2}{*}{ Output gap } & 0.2077 & 0.1495 & $0.3131 * *$ \\
\hline & $(0.1389)$ & $(0.1610)$ & $(0.1260)$ \\
\hline \multirow[t]{2}{*}{ RER } & -0.0218 & -0.2457 & 0.3558 \\
\hline & $(0.1302)$ & $(0.5323)$ & $(0.2278)$ \\
\hline \multicolumn{4}{|l|}{ Difference } \\
\hline \multirow[t]{2}{*}{ Constant } & & 2.3756 & $1.8214 * *$ \\
\hline & & $(1.5863)$ & $(0.9042)$ \\
\hline \multirow[t]{2}{*}{ Inflation gap } & & $-3.2184 * * *$ & $-2.2697 * * *$ \\
\hline & & $(0.4377)$ & $(0.3913)$ \\
\hline \multirow[t]{2}{*}{ Output gap } & & -0.3842 & $-0.5650 * * *$ \\
\hline & & $(0.277)$ & $(0.1908)$ \\
\hline \multirow[t]{2}{*}{ RER } & & $-0.5849 * * *$ & -0.1369 \\
\hline & & $(0.1953)$ & $(0.1754)$ \\
\hline \multirow[t]{2}{*}{ IMR } & & -0.2191 & $0.7251 * *$ \\
\hline & & $(0.7092)$ & $(0.3607)$ \\
\hline JSSE & & 0.5775 & 0.5872 \\
\hline No. of high regime & & $97 / 174$ & $77 / 174$ \\
\hline
\end{tabular}

Note: The instrumental variables for the model are first and twelfth lags of inflation gap, output gap and real exchange rate. Values in paranthesis are standard errors. $* * * * * * *$ denote significance at $10 \%, 5 \%$ and $1 \%$ significance levels. JSSE refers to joint sum of squares and IMR refers to inverse Mill ratio.

Hansen (2000) LM-test in Table 5 shows that models with all the threshold candidates reject the null of linearity at 10\% significance level. The STR model using GMM selects the model with the threshold variable output gap according to J-statistics, however the threshold estimate is observed to insignificant. Again, only the model with RER as the threshold variable has significant threshold effect.

The test results for Model 2, given in Table 6 are in line with the results in Model 1, such that RER has a negative effect in the low regime period (depreciated currency), whereas inflation gap has a positive effect on the real policy rate gap (using natural real policy rate) in the high regime period (appreciated currency). In addition to these findings, Model 2 shows a positive effect of output gap in the appreciated currency period. Hence, the high regime period fits the 
Review of Economic Analysis 12 (2020) 167-202

Table 5: Threshold estimates for Model 2

\begin{tabular}{l|cc|cc|c}
\hline Threshold & \multicolumn{2}{|c|}{ Hansen Test } & \multicolumn{2}{c|}{ GMM } & 2SLS \\
Candidates & LM-test & Threshold & J-stat & Threshold & Threshold \\
\hline Inflation gap & 14.3985 & 0.0478 & 4.0896 & 0.0106 & 0.0247 \\
& $(0.033)$ & {$[0.0170,0.0574]$} & & {$[-0.0089,0.0487]$} & {$[-0.0089,0.0487]$} \\
Output gap & 13.0258 & -0.024 & 2.812 & -0.0044 & -0.0250 \\
& $(0.065)$ & {$[0.034,0.0200]$} & & {$[-0.05,0.0458]$} & {$[-0.05,0.0458]$} \\
RER & 17.3548 & 4.5623 & 5.4897 & 4.6687 & 4.5623 \\
& $(0.005)$ & {$[0.5622,4.5886]$} & & {$[4.5096,4.7878]$} & {$[4.5096,4.7878]$} \\
Interest rate & 21.781 & 0.0662 & 8.5652 & 0.0262 & 0.0262 \\
& $(0.001)$ & {$[0.0061,0.0711]$} & & {$[-0.0713,0.0962]$} & {$[-0.0713,0.0962]$} \\
\hline \hline
\end{tabular}

Note: As in Table 3

expectations from a standard central bank policy standpoint as both the inflation and output gaps display positive and significant effects.

\section{Conclusion}

This study examines how policy rate is determined in Turkish economy using two Taylor rule models. As an open developing economy, it seems highly possible that there is not a single rule followed by CBRT as also argued by several empirical work in the literature (Kara et al., 2007; Gürkaynak et al., 2015; Caporale et al., 2018). Dummy variables, structural breaks, sample splitting models are some of the options to handle nonlinearity issues. However, threshold regression models stand out since these techniques estimate the threshold parameters and hence are less restrictive compared to time-dependent regime switching models. Kourtellos et al. (2016), differently from the previous threshold models, allows for endogeneity for the threshold variables. In this paper, we employ GMM and two stages least squares methodology of Kourtellos et al. (2016).

In the empirical work, real exchange rate is added to the standard Taylor rule model and is selected as the preferred threshold variable by the employed test statistics. Our estimates indicate the Taylor rule implies different behaviors according to whether the real exchange is above or below the threshold. In the appreciated currency period, when CBRT has no need to have concerns on currency due its adverse effects on inflation, the Taylor rule exhibits its expected characteristics and indicates that CBRT adjust interest rate according to inflation and output.

However, in the times of currency depreciation, CBRT may appear to lose its main policy objective of inflation targeting and focuses on the depreciation of the currency. We think that this interpretation should be taken with caution. It is widely known that Turkish economy is highly dependent on imported inputs and exchange rate depreciations cause to inflation via passthrough mechanism. Moreover, currency depreciations deteriorate confidence, worsen inflation expectations, and have the potential of leading to depreciation-inflation spiral (Arbal1, 2003; 
DENIZ, STENGOS, YAZGAN Taylor Rule Model for Turkey

Table 6: Threshold Test Results for Model 2

\begin{tabular}{|c|c|c|c|}
\hline Variables & Hansen test & GMM & 2SLS \\
\hline Regime 1 & $R E R_{t}<\hat{\gamma}_{r e r}$ & $R E R_{t}<\hat{\gamma}_{\text {rer }}$ & $R E R_{t}<\hat{\gamma}_{r e r}$ \\
\hline \multirow[t]{2}{*}{ Constant } & $0.8232^{* * *}$ & 0.055 & $0.8698 * * *$ \\
\hline & $(0.2114)$ & $(0.3633)$ & $(0.2939)$ \\
\hline \multirow[t]{2}{*}{ Lagged LHS } & $0.1946^{*}$ & $1.0459 * * *$ & 0.2266 \\
\hline & $(0.1134)$ & $(0.0847)$ & $(0.2584)$ \\
\hline \multirow[t]{2}{*}{ Inflation gap } & $0.5900^{* * *}$ & 0.2789 & 0.5967 \\
\hline & $(0.2476)$ & $(0.2284)$ & $(0.4185)$ \\
\hline \multirow[t]{2}{*}{ Output gap } & 0.1472 & 0.0155 & 0.1517 \\
\hline & $(0.1262)$ & $(0.0324)$ & $(0.1731)$ \\
\hline \multirow[t]{2}{*}{ RER } & $-0.1916 * * *$ & -0.0248 & $-0.2107 * * *$ \\
\hline & $(0.0461)$ & $(0.0915)$ & $(0.0684)$ \\
\hline Regime 2 & $R E R_{t}>\hat{\gamma}_{r e r}$ & $R E R_{t}>\hat{\gamma}_{\text {rer }}$ & $R E R_{t}>\hat{\gamma}_{r e r}$ \\
\hline \multirow[t]{2}{*}{ Constant } & 0.0568 & 0.3589 & 0.2297 \\
\hline & $(0.0346)$ & $(0.4186)$ & $(0.2220)$ \\
\hline \multirow[t]{2}{*}{ Lag LHS } & $0.9820 * * *$ & $0.9451 * * *$ & $0.9828 * * *$ \\
\hline & $(0.0072)$ & $(0.0365)$ & $(0.0091)$ \\
\hline \multirow[t]{2}{*}{ Inflation gap } & $0.0630 * * *$ & 0.0429 & $0.0649 * *$ \\
\hline & $(0.0254)$ & $(0.0445)$ & $(0.0312)$ \\
\hline \multirow[t]{2}{*}{ Output gap } & $0.0457 * * *$ & $0.0662 * * *$ & $0.0445 * * *$ \\
\hline & $(0.0125)$ & $(0.0163)$ & $(0.0102)$ \\
\hline \multirow[t]{2}{*}{ RER } & $-0.0127 *$ & -0.0652 & -0.0417 \\
\hline & $(0.0073)$ & $(0.0732)$ & $(0.0384)$ \\
\hline \multicolumn{4}{|l|}{ Difference } \\
\hline \multirow[t]{2}{*}{ Constant } & & -0.3039 & $0.6401 * *$ \\
\hline & & $(0.2606)$ & $(0.3218)$ \\
\hline \multirow[t]{2}{*}{ Lag LHS } & & 0.1008 & $-0.7563 * * *$ \\
\hline & & $(0.0976)$ & $(0.2582)$ \\
\hline \multirow[t]{2}{*}{ Inflation gap } & & 0.236 & 0.5318 \\
\hline & & $(0.2284)$ & $(0.4194)$ \\
\hline \multirow[t]{2}{*}{ Output gap } & & -0.0507 & 0.1072 \\
\hline & & $(0.0359)$ & $(0.1735)$ \\
\hline \multirow[t]{2}{*}{ RER } & & 0.0404 & $-0.169 * * *$ \\
\hline & & $(0.0493)$ & $(0.0647)$ \\
\hline \multirow[t]{2}{*}{ IMR } & & -0.0697 & -0.0517 \\
\hline & & $(0.0958)$ & $(0.0593)$ \\
\hline JSSE & & 0.51518 & 0.0062 \\
\hline No. of high regime & & 97 & 149 \\
\hline
\end{tabular}

Note: As in Table 4. Lagged LHS refers to the lagged value of left hand side (dependent) variable variable.

Kara et al., 2007; Kara and Öğünç, 2008; Karagöz et al., 2016; Civcir and Akçağlayan, 2010; López-Villavicencio and Mignon, 2017). As emphasized by Benlialper and Cömert (2015), because of its impact on inflation, exchange rate appreciation has played an important role as a dis-inflationary tool in Turkey. Hence focusing on the currency depreciation may not necessary mean that CBRT loses its objective of fighting inflation. As indicated in the introduction, after the great financial crisis of 2009, the newly adopted macro-prudential approach has rendered Turkish central bank more cautious about financial stability. As in many emerging markets, in Turkey, financial stability is always considered closely linked to exchange rate stability. By also 
following the famous fear of floating argument of Calvo and Reinhart (2002) it can be argued that keeping exchange rate stable is crucial since fluctuations can deteriorate the confidence on the economy leading to capital outflows that further destabilize exchange rates which hampers the implementation of inflation targeting. Consequently, when the currency depreciation is above certain threshold it is certainly possible that its priority dominates monetary policy.

\section{References}

Aklan, N. A. and Nargelecekenler, M. (2008), Taylor rule in practice: Evidence from Turkey, International Advances in Economic Research 14(2), 156-166.

Alp, H., Ogunc, F. and Sarikaya, C. (2012), Monetary Policy and Output Gap : Mind the Composition, CBT Research Notes in Economics No: 1207, Central Bank of the Republic of Turkey.

Arbal1, E. C. (2003), Exchange Rate Pass-Through In Turkey: Looking for Asymmetries., Central Bank Review 3(2), 85-124.

Benlialper, A. and Cömert, H. (2015), Implicit asymmetric exchange rate peg under inflation targeting regimes: the case of Turkey, Cambridge Journal of Economics 40(6), 1553-1580.

Çağlayan, E. and Astar, M. (2010), Taylor Rule: Is it an Applicable Guide for Inflation Targeting Countries, Journal of Money Investment and Banking 18, 55-67.

Calvo, G. A. and Reinhart, C. M. (2002), Fear of floating, The Quarterly Journal of Economics 117(2), 379-408.

Caner, M. and Hansen, B. E. (2004), Instrumental variable estimation of a threshold model, Econometric Theory 20(5), 813-843.

Caporale, G. M., Helmi, M. H., Çatık, A. N., Ali, F. M. and Akdeniz, C. (2018), Monetary policy rules in emerging countries: Is there an augmented nonlinear taylor rule?, Economic Modelling 72, 306-319.

Castro, V. (2011), Can central banks monetary policy be described by a linear (augmented) Taylor rule or by a nonlinear rule?, Journal of Financial Stability 7(4), 228-246.

CBRT (2018), Central Bank of the Republic of Turkey, Inflation Report 2018-III.

Civcir, I. and Akçağlayan, A. (2010), Inflation targeting and the exchange rate: Does it matter in Turkey?, Journal of Policy Modeling 32(3), 339-354.

Clarida, R., Gali, J. and Gertler, M. (2000), Monetary policy rules and macroeconomic stability: evidence and some theory, The Quarterly Journal of Economics 115(1), 147-180.

Demiralp, S. and Demiralp, S. (2019), Erosion of Central Bank Independence in Turkey, Turkish Studies 20(1), 49-68.

Dincer, N. N. and Eichengreen, B. (2014), Central bank transparency and independence: updates and new measures, International Journal of Central Banking 10(1), 189-253.

Erdem, E. and Kayhan, S. (2011), The Taylor rule in estimating the performance of inflation targeting programs: the case of Turkey, Global Economy Journal 11(1), 185-219. 


\section{DENIZ, STENGOS, YAZGAN Taylor Rule Model for Turkey}

Ersel, H. and Özatay, F. (2008), Fiscal dominance and inflation targeting: Lessons from Turkey, Emerging Markets Finance and Trade 44(6), 38-51.

Fernandez, A. Z., Koenig, E. F. and Nikolsko-Rzhevskyy, A. (2010), Can alternative Taylorrule specifications describe Federal Reserve policy decisions?, Journal of Policy Modeling 32(6), 733-757.

Froyen, R. T. and Guender, A. V. (2018), The real exchange rate in Taylor rules: A ReAssessment, Economic Modelling 73, 140-151.

Güney, P. Ö. (2016), Does the central bank directly respond to output and inflation uncertainties in Turkey?, Central Bank Review 16(2), 53-57.

Gürkaynak, R. S., Kantur, Z., Taş, M. A. and Yıldırım, S. (2015), Monetary policy in Turkey after Central Bank independence, Iktisat Isletme ve Finans 30(356), 9-38.

Hamilton, J. D. (2018), Why you should never use the Hodrick-Prescott filter, Review of Economics and Statistics 100(5), 831-843.

Hansen, B. E. (2000), Sample splitting and threshold estimation, Econometrica 68(3), 575-603.

Kara, H. (2012), Küresel kriz sonrası para politikası, Iktisat Işletme ve Finans 27(315), 9-36.

Kara, H. (2016), A brief assessment of Turkey's macroprudential policy approach: 2011-2015, Central Bank Review 16(3), 85-92.

Kara, H. and Ögüuç, F. (2008), Inflation targeting and exchange rate pass-through: the Turkish experience, Emerging Markets Finance and Trade 44(6), 52-66.

Kara, H., Öünç, F., Özlale, Ü. and Sarikaya, Ç. (2007), Estimating the output gap in a changing economy, Southern Economic Journal 74(1), 269-289.

Karagöz, M., Demirel, B. and Bozdağ, E. G. (2016), Pass-through Effect from Exchange Rates to the Prices in the Framework of Inflation Targeting Policy: A Comparison of Asia-Pacific, South American and Turkish Economies, Procedia Economics and Finance 38, 438-445.

Khakimov, O. A., Erdogan, L. and Uslu, N. Ç. (2010), Assessing Monetary Policy Rule in Turkey, International Journal of Economic Perspectives 4(1), 319.

Kourtellos, A., Stengos, T. and Tan, C. M. (2016), Structural threshold regression, Econometric Theory 32(4), 827-860.

Küçük, H., Özlü, P., Talasl1, İ. A., Ünalmış, D. and Yüksel, C. (2016), Interest rate corridor, liquidity management, and the overnight spread, Contemporary Economic Policy 34(4), 746761.

Lee, J. and Strazicich, M. C. (2003), Minimum Lagrange multiplier unit root test with two structural breaks, Review of Economics and Statistics 85(4), 1082-1089.

López-Villavicencio, A. and Mignon, V. (2017), Exchange rate pass-through in emerging countries: Do the inflation environment, monetary policy regime and central bank behavior matter?, Journal of International Money and Finance 79, 20-38.

Martin, C. and Milas, C. (2004), Modelling monetary policy: inflation targeting in practice, Economica 71(282), 209-221. 
Martin, C. and Milas, C. (2013), Financial crises and monetary policy: Evidence from the UK, Journal of Financial Stability 9(4), 654-661.

Mohanty, M. S. and Klau, M. (2005), Monetary policy rules in emerging market economies: issues and evidence, Monetary policy and macroeconomic stabilization in Latin America, Springer, pp. 205-245.

Öğünç, F. and Batmaz, I. (2011), Estimating the neutral real interest rate in an emerging market economy, Applied Economics 43(6), 683-693.

Orphanides, A. (2003), Historical monetary policy analysis and the Taylor rule, Journal of Monetary Economics 50(5), 983-1022.

Ozel, I. (2012), The politics of de-delegation: Regulatory (in) dependence in Turkey, Regulation $\mathcal{E}$ Governance 6(1), 119-129.

Phillips, P. C. and Perron, P. (1988), Testing for a unit root in time series regression, Biometrika 75(2), 335-346.

Taylor, J. B. (1993), Discretion versus policy rules in practice, Carnegie-Rochester Conference Series on Public Policy, Vol. 39, Elsevier, pp. 195-214.

Taylor, J. B. (2001), The role of the exchange rate in monetary-policy rules, American Economic Review 91(2), 263-267.

Us, V. (2007), Alternative monetary policy rules in the Turkish economy under an inflationtargeting framework, Emerging Markets Finance and Trade 43(2), 82-101.

Yazgan, M. E. and Yilmazkuday, H. (2007), Monetary policy rules in practice: evidence from Turkey and Israel, Applied Financial Economics 17(1), 1-8.

Yellen, J. (2005), "The Yellen View", International Economy, http://www . international-economy.com/TIE_Sp05_Yellen.pdf.

\section{Appendix A: Linear GMM analysis for alternative models}

Table A. 1 provides the results of linear GMM estimation for the following seven alternative models.

\section{Model 1}

$i_{t}=\beta_{0}+\beta_{1}\left(\pi_{t}-\pi_{t}^{T}\right)+\beta_{2} \tilde{y}_{t}+\beta_{3}$ rer $_{t}+u_{t}$,

where $i_{t}$ is official policy rates as explained in the data section, $\tilde{y}_{t}$ is the output gap using HP filter, $r e r_{t}$ is the real effective exchange rate as explained in the data section. In this model, inflation gap is employed as the difference between contemporaneous inflation and inflation target.

\section{Model 2}

$$
r_{t}-r_{t-1}^{*}=\beta_{0}+\beta_{1}\left(r_{t-1}-r_{t-1}^{*}+\beta_{2} E_{t}\left(\pi_{\text {end }}-\pi_{t}^{T}\right)+\beta_{3} \tilde{y}_{t}+\beta_{4} r e r_{t}+u_{t},\right.
$$

where $r_{t}$ is the real interest rate which is calculated as nominal interest rate minus contemporaneous inflation rate, $r^{*}$ is the natural real interest rate as explained in Section 3.3. $E_{t} \pi_{\text {end }}$ is 
expected end of year inflation. Expected inflation for the end of year is obtained from the survey of expectations of CBRT.

\section{Model 3}

$\Delta i_{t}=\beta_{0}+\beta_{1}\left(E_{t} \pi_{\text {end }}-\pi_{t}^{T}\right)+\beta_{2} \tilde{u}_{t}+\beta_{3}$ rer $_{t}+u_{t}$,

where $\tilde{u}_{t}$ is the unemployment gap. Unemployment gap is the difference between NAIRU and unemployment rate where NAIRU is calculated by regressing the first difference of inflation on unemployment rate using the following model: $\pi_{t}-\pi_{t}^{e}=-a\left(u-u_{t}^{*}\right)+v_{t}$, where we assume adaptive expectations, so that $\pi_{t}^{e}=\pi_{t-1}$ and constant non-accelarating inflation rate of unemployment as defined in Ball and Mankiw (2002). In this model nominal interest rate is assumed to be non-stationary, and its first difference, $\Delta i_{t}$, is used in the estimation.

\section{Model 4}

$\Delta i_{t}=\beta_{0}+\beta_{1}\left(\pi_{t}-\pi_{t}^{T}\right)+\beta_{2} \tilde{y}_{t}+\beta_{3} \operatorname{rer}_{t}+u_{t}$,

\section{Model 5}

$\Delta r_{t}=\beta_{0}+\beta_{1}\left(E_{t} \pi_{\text {end }}-\pi_{t}^{T}\right)+\beta_{2} \tilde{y}_{t}+\beta_{3}$ rer $_{t}+u_{t}$

\section{Model 6}

$\Delta i_{t}=\beta_{0}+\beta_{1}\left(E_{t} \pi_{\text {end }}-\pi_{t}^{T}\right)+\beta_{2} \tilde{y}_{t}+\beta_{3} x_{r v o l}+u_{t}$,

where $\mathrm{xrvol}_{t}$ is the exchange rate volatility using monthly standard deviations of daily data.

\section{Model 7}

$\Delta i_{t}=\beta_{0}+\beta_{1}\left(E_{t} \pi_{\text {end }}-\pi_{t}^{T}\right)+\beta_{2} \tilde{y_{t}}+\beta_{3} r e r_{t}+u_{t}$

\section{Appendix B: Threshold analysis for the 7 alternative models outlined in Ap- pendix A}

\section{Model 1:}

$$
\begin{aligned}
i_{t}=I\left(q_{t} \leq \gamma\right)\left(\beta_{0}^{L}+\beta_{1}^{L}\left(\pi_{t}-\pi_{t}^{T}\right)+\right. & \left.\beta_{2}^{L} \tilde{y}_{t}+\beta_{3}^{L} \operatorname{rer}_{t}\right) \\
& +I\left(q_{t}>\gamma\right)\left(\beta_{0}^{H}+\beta_{1}^{H}\left(\pi_{t}-\pi_{t}^{T}\right)+\beta_{2}^{H} \tilde{y}_{t}+\beta_{3}^{H} \operatorname{rer}_{t}\right)+u_{t}
\end{aligned}
$$


Review of Economic Analysis 12 (2020) 167-202

Table A. 1: Linear - GMM models

\begin{tabular}{|c|c|c|c|c|c|c|c|}
\hline Variables & (1) & (2) & (3) & (4) & $(5)$ & (6) & (7) \\
\hline Constant & $\begin{array}{c}0.0764 * * * \\
(0.0289)\end{array}$ & $\begin{array}{c}0.0710 * * \\
(0.0294)\end{array}$ & $\begin{array}{l}0.0650^{*} \\
(0.0378)\end{array}$ & $\begin{array}{c}0.1192 * * * \\
(0.0428)\end{array}$ & $\begin{array}{c}-0.1832 \\
(0.2649)\end{array}$ & $\begin{array}{c}-0.0086^{* * * *} \\
(0.0032)\end{array}$ & $\begin{array}{c}-0.0395 \\
(0.04267)\end{array}$ \\
\hline Lagged LHS & & $\begin{array}{c}0.9885 * * * \\
(0.0088)\end{array}$ & & & & & \\
\hline Inflation gap & $\begin{array}{l}0.0644 * * \\
(0.03071)\end{array}$ & $\begin{array}{l}0.0493^{*} \\
(0.0272)\end{array}$ & $\begin{array}{c}-0.0262 \\
(0.0379)\end{array}$ & $\begin{array}{c}-0.0605^{*} \\
(0.0365)\end{array}$ & $\begin{array}{c}-0.0139 \\
(0.3483)\end{array}$ & $\begin{array}{c}-0.1865^{* *} \\
(0.0914)\end{array}$ & $\begin{array}{c}0.1026 * * * \\
(0.0357)\end{array}$ \\
\hline Output gap & $\begin{array}{c}0.0260 \\
(0.0175)\end{array}$ & $\begin{array}{c}0.0344^{* * *} \\
(0.0117)\end{array}$ & & $\begin{array}{c}0.0881 * * * \\
(0.0274)\end{array}$ & $\begin{array}{l}0.3055^{*} \\
(0.1670)\end{array}$ & $\begin{array}{c}0.1143 * * * \\
(0.0360)\end{array}$ & $\begin{array}{c}-0.0523 * * \\
(0.0267)\end{array}$ \\
\hline Unemployment gap & & & $\begin{array}{c}0.0004 \\
(0.0007)\end{array}$ & & & & \\
\hline RER & $\begin{array}{c}-0.0168 * * * \\
(0.0061)\end{array}$ & $\begin{array}{c}-0.0156^{* * * *} \\
(0.0062)\end{array}$ & $\begin{array}{l}-0.0138^{*} \\
(0.0080)\end{array}$ & $\begin{array}{c}-0.0252 * * * \\
(0.0091)\end{array}$ & $\begin{array}{c}0.0669 \\
(0.0554)\end{array}$ & & $\begin{array}{c}0.0076 \\
(0.0090)\end{array}$ \\
\hline XRVOL & & & & & & $\begin{array}{c}0.4592 * * * \\
(0.1607)\end{array}$ & \\
\hline
\end{tabular}

Note: Lagged LHS refers to the lagged value of left hand side (dependent) variable variable. RHS (right hand side) variables are instrumented using their lagged values. Values in parentheses are robust standard errors. $*, * *, * * *$ denote significance at $1 \%, 5 \%$ and $10 \%$ significance levels.

Table B. 1: Hansen (2000) for Model 1

\begin{tabular}{|c|c|c|c|c|}
\hline Threshold variable & inflation gap & output gap & rer & interest rate \\
\hline Threshold estimate & 0.0039 & 0.0112 & 4.6619 & 0.1550 \\
\hline 95\% C.I. & {$[-0.0001,0.0070]$} & {$[0.0056,0.0249]$} & {$[4.6283,4.7101]$} & {$[0.1350,0.1550]$} \\
\hline Regime 1 & $\pi \leq \gamma_{\pi}$ & $\pi \leq \gamma_{\tilde{y}}$ & $\pi \leq \gamma_{\text {rer }}$ & $\pi \leq \gamma_{i}$ \\
\hline \multirow[t]{2}{*}{ Constant } & $5.5603 * * *$ & $0.9694 * * *$ & $2.1800^{* * *}$ & $0.8710^{* * *}$ \\
\hline & $(0.9764)$ & $(0.3117)$ & $(0.5137)$ & $(0.1320)$ \\
\hline \multirow[t]{2}{*}{ Inflation gap } & 1.6458 & $-0.6782 * * *$ & $-1.3848 * * *$ & -0.0499 \\
\hline & $(1.0419)$ & $(0.2317)$ & $(0.3128)$ & $(0.1230)$ \\
\hline \multirow[t]{2}{*}{ Output gap } & $0.3433 * *$ & -0.0399 & -0.2996 & $-0.3401 * * *$ \\
\hline & $(0.1683)$ & $(0.1701)$ & $(0.2292)$ & $(0.0592)$ \\
\hline \multirow[t]{2}{*}{ RER } & $-1.1429 * * *$ & $-0.1783 * * *$ & $-0.4422 * * *$ & $-0.1698 * * *$ \\
\hline & $(0.2060)$ & $(0.0666)$ & $(0.1111)$ & $(0.0280)$ \\
\hline Regime 2 & $\pi>\gamma_{\pi}$ & $\pi>\gamma_{\tilde{y}}$ & $\pi>\gamma_{\text {rer }}$ & $\pi>\gamma_{i}$ \\
\hline \multirow[t]{2}{*}{ Constant } & $-0.8394 * * *$ & $-1.4435 * * *$ & 0.2250 & $0.5941 * * *$ \\
\hline & $(0.1999)$ & $(0.3655)$ & $(0.6170)$ & $(0.1609)$ \\
\hline \multirow[t]{2}{*}{ Inflation gap } & $1.6826^{* * *}$ & $1.2027 * * *$ & $0.7483 * * *$ & $-0.3033 * * *$ \\
\hline & $(0.2456)$ & $(0.3063)$ & $(0.2334)$ & $(0.0903)$ \\
\hline \multirow[t]{2}{*}{ Output gap } & 0.1789 & 0.0698 & 0.2077 & 0.0979 \\
\hline & $(0.1323)$ & $(0.4577)$ & $(0.1389)$ & $(0.0793)$ \\
\hline \multirow[t]{2}{*}{ RER } & $0.1916^{* * *}$ & $0.3274 * * *$ & -0.0218 & $-0.0794 * *$ \\
\hline & $(0.0423)$ & $(0.0798)$ & $(0.1302)$ & $(0.0342)$ \\
\hline LM-test & 48.2661 & 36.7058 & 32.2128 & 115.8041 \\
\hline Bootstrap P-Value & 0.0000 & 0.0000 & 0.0000 & 0.0000 \\
\hline
\end{tabular}

Note:Values in paranthesis are standard errors. $*, * * * * *$ denote significance at $10 \%, 5 \%$ and $1 \%$ significance levels. 
DENIZ, STENGOS, YAZGAN Taylor Rule Model for Turkey

Table B. 2: Structural regression model using GMM for Model 1

\begin{tabular}{|c|c|c|c|c|}
\hline $\begin{array}{l}\text { Threshold variable } \\
\text { Threshold estimate } \\
\text { 95\% C.I. }\end{array}$ & $\begin{array}{c}\text { inflation gap } \\
-0.0017 \\
{[-0.0151,0.062]}\end{array}$ & $\begin{array}{c}\text { output gap } \\
0.0000 \\
{[-0.05,0.05]}\end{array}$ & $\begin{array}{c}\text { rer } \\
4.6687 \\
{[4.5096,4.7878]}\end{array}$ & $\begin{array}{c}\text { interest rate } \\
0.1400 \\
{[0.06,0.23]}\end{array}$ \\
\hline Regime 1 & $\pi \leq \gamma_{\pi}$ & $\pi \leq \gamma_{\tilde{y}}$ & $\pi \leq \gamma_{r e r}$ & $\pi \leq \gamma_{i}$ \\
\hline Constant & $\begin{array}{c}19.5147 * * * \\
(3.3289)\end{array}$ & $\begin{array}{l}0.8138^{*} \\
(0.4606)\end{array}$ & $\begin{array}{c}3.8181 * * \\
(1.6786)\end{array}$ & $\begin{array}{c}1.3508 * * * \\
(0.1220)\end{array}$ \\
\hline Inflation gap & $\begin{array}{c}16.0191 * * * \\
(3.0555)\end{array}$ & $\begin{array}{c}-1.3190 * * * \\
(0.3620)\end{array}$ & $\begin{array}{c}-2.1986^{* * *} \\
(0.3555)\end{array}$ & $\begin{array}{l}-0.1405 \\
(0.1046)\end{array}$ \\
\hline Output gap & $\begin{array}{l}0.7963^{*} \\
(0.4067)\end{array}$ & $\begin{array}{l}-0.2620 \\
(0.3576)\end{array}$ & $\begin{array}{l}-0.2348 \\
(0.2270)\end{array}$ & $\begin{array}{c}-0.3138 * * * \\
(0.0526)\end{array}$ \\
\hline RER & $\begin{array}{c}-2.6007 * * * \\
(0.3750)\end{array}$ & $\begin{array}{c}-0.3096 * * * \\
(0.0580)\end{array}$ & $\begin{array}{l}-0.8306^{*} \\
(0.4785)\end{array}$ & $\begin{array}{c}-0.1822 * * * \\
(0.0233)\end{array}$ \\
\hline Regime 2 & $\pi>\gamma_{\pi}$ & $\pi>\gamma_{\tilde{y}}$ & $\pi>\gamma_{r e r}$ & $\pi>\gamma_{i}$ \\
\hline Constant & $\begin{array}{c}-8.2207 * * * \\
(1.8161)\end{array}$ & $\begin{array}{c}-1.1068^{* *} \\
(0.4359)\end{array}$ & $\begin{array}{c}1.4425 \\
(3.0350)\end{array}$ & $\begin{array}{c}0.2488 \\
(0.3918)\end{array}$ \\
\hline Inflation gap & $\begin{array}{c}8.3658 * * * \\
(1.7259)\end{array}$ & $\begin{array}{c}1.1293 * * * \\
(0.3095)\end{array}$ & $\begin{array}{c}1.0198 * * * \\
(0.2368)\end{array}$ & $\begin{array}{c}-0.2695^{*} \\
(0.1505)\end{array}$ \\
\hline Output gap & $\begin{array}{c}-0.7569 * * \\
(0.3834)\end{array}$ & $\begin{array}{l}-1.3775 \\
(1.0921)\end{array}$ & $\begin{array}{c}0.1495 \\
(0.1610)\end{array}$ & $\begin{array}{c}0.3943 * * * \\
(0.1371)\end{array}$ \\
\hline RER & $\begin{array}{c}0.2918^{* * * *} \\
(0.0809)\end{array}$ & $\begin{array}{c}0.4326 * * * \\
(0.1094)\end{array}$ & $\begin{array}{c}-0.2457 \\
(0.5323) \\
\end{array}$ & $\begin{array}{l}-0.0967 \\
(0.0764)\end{array}$ \\
\hline \multicolumn{5}{|l|}{ Difference } \\
\hline Constant & $\begin{array}{c}27.7354 * * * \\
(5.0319)\end{array}$ & $\begin{array}{c}1.9206 * * * \\
(0.7487)\end{array}$ & $\begin{array}{c}2.3756 \\
(1.5863)\end{array}$ & $\begin{array}{c}1.1020 * * * \\
(0.4374)\end{array}$ \\
\hline Inflation gap & $\begin{array}{c}7.6532 * * * \\
(2.2501)\end{array}$ & $\begin{array}{c}-2.4483 * * * \\
(0.4704)\end{array}$ & $\begin{array}{c}-3.2184 * * * \\
(0.4377)\end{array}$ & $\begin{array}{c}0.1290 \\
(0.1858)\end{array}$ \\
\hline Output gap & $\begin{array}{c}1.5532 * * * \\
(0.5723)\end{array}$ & $\begin{array}{c}1.1156 \\
(0.9317)\end{array}$ & $\begin{array}{c}-0.3842 \\
(0.2770)\end{array}$ & $\begin{array}{c}-0.7081 * * * \\
(0.1450)\end{array}$ \\
\hline RER & $\begin{array}{c}-2.8925 * * * \\
(0.3802)\end{array}$ & $\begin{array}{c}-0.7423 * * * \\
(0.1361)\end{array}$ & $\begin{array}{c}-0.5849 * * * \\
(0.1953) \\
\end{array}$ & $\begin{array}{c}-0.0855 \\
(0.0784) \\
\end{array}$ \\
\hline IMR(kappa) & $\begin{array}{c}8.6157 * * * \\
(2.2435)\end{array}$ & $\begin{array}{l}-0.9849 \\
(0.6157)\end{array}$ & $\begin{array}{l}-0.2191 \\
(0.7092)\end{array}$ & $\begin{array}{c}0.5325 * * * \\
(0.1399)\end{array}$ \\
\hline JSSE & 0.4514 & 0.6479 & 0.5775 & 0.0902 \\
\hline JSTAT & 4.5242 & 22.5194 & 8.5986 & 25.9689 \\
\hline Upper regime $(\%)$ & $147 / 174$ & $88 / 174$ & $97 / 174$ & $63 / 174$ \\
\hline
\end{tabular}

Note: The instrumental variables for the model are first and twelfth lags of inflation gap, output gap and real exchange rate.. Values in paranthesis are standard errors. $*, * *, * * *$ denote significance at $1 \%, 5 \%$ and $10 \%$ significance levels. JSSE is short for joint sum of squares. 
Review of Economic Analysis 12 (2020) 167-202

Table B. 3: Structural threshold regression using Least Squares for Model 1

\begin{tabular}{|c|c|c|c|c|}
\hline Threshold variable & inflation gap & output gap & rer & interest rate \\
\hline Threshold estimate & 0.0039 & 0.0100 & 4.7005 & 0.1400 \\
\hline 95\% C.I. & {$[-0.0151,0.062]$} & {$[-0.05,0.05]$} & {$[4.5096,4.7878]$} & {$[0.06,0.23]$} \\
\hline Regime 1 & $\pi \leq \gamma_{\pi}$ & $\pi \leq \gamma_{\tilde{y}}$ & $\pi \leq \gamma_{\text {rer }}$ & $\pi \leq \gamma_{i}$ \\
\hline \multirow[t]{2}{*}{ Constant } & $5.4716^{* * *}$ & 0.4143 & -0.3148 & $1.0083^{* * *}$ \\
\hline & $(1.1148)$ & $(0.3551)$ & $(0.8098)$ & $(0.1724)$ \\
\hline \multirow[t]{2}{*}{ Inflation gap } & $1.6478 *$ & $-0.6501 * *$ & $-1.1553 * * *$ & -0.0451 \\
\hline & $(0.9006)$ & $(0.3196)$ & $(0.3415)$ & $(0.0734)$ \\
\hline \multirow[t]{2}{*}{ Output gap } & $0.3211 *$ & -0.1612 & $-0.2519 *$ & $-0.2948 * * *$ \\
\hline & $(0.1775)$ & $(0.2230)$ & $(0.1420)$ & $(0.0528)$ \\
\hline \multirow[t]{2}{*}{ RER } & $-1.1309 * * *$ & $-0.1313 * *$ & 0.2189 & $-0.1629 * * *$ \\
\hline & $(0.1346)$ & $(0.0580)$ & $(0.2276)$ & $(0.0189)$ \\
\hline Regime 2 & $\pi>\gamma_{\pi}$ & $\pi>\gamma_{\tilde{y}}$ & $\pi>\gamma_{\text {rer }}$ & $\pi>\gamma_{i}$ \\
\hline \multirow[t]{2}{*}{ Constant } & -0.8173 & $-1.4255^{* * *}$ & -2.1362 & 0.4145 \\
\hline & $(0.6376)$ & $(0.5211)$ & $(1.3057)$ & $(0.4162)$ \\
\hline \multirow[t]{2}{*}{ Inflation gap } & $1.6658 * * *$ & $1.0649 * * *$ & $1.1144 * * *$ & $-0.3066^{* * *}$ \\
\hline & $(0.3671)$ & $(0.2378)$ & $(0.1916)$ & $(0.1226)$ \\
\hline \multirow[t]{2}{*}{ Output gap } & 0.1819 & -0.2781 & $0.3131 * *$ & $0.1855^{* *}$ \\
\hline & $(0.1243)$ & $(0.3874)$ & $(0.1260)$ & $(0.0805)$ \\
\hline \multirow[t]{2}{*}{ RER } & $0.1940 * * *$ & $0.3992 * * *$ & 0.3558 & -0.0775 \\
\hline & $(0.0307)$ & $(0.0710)$ & $(0.2278)$ & $(0.0628)$ \\
\hline \multicolumn{5}{|l|}{ Difference } \\
\hline \multirow[t]{2}{*}{ Constant } & $6.2888^{* * *}$ & $1.8399 * * *$ & $1.8214 * *$ & 0.5938 \\
\hline & $(1.6843)$ & $(0.7750)$ & $(0.9042)$ & $(0.5510)$ \\
\hline \multirow[t]{2}{*}{ Inflation gap } & -0.0180 & $-1.7150 * * *$ & $-2.2697 * * *$ & $0.2614^{*}$ \\
\hline & $(0.8241)$ & $(0.4003)$ & $(0.3913)$ & $(0.1447)$ \\
\hline \multirow[t]{2}{*}{ Output gap } & 0.1393 & 0.1169 & $-0.5650 * * *$ & $-0.4803 * * *$ \\
\hline & $(0.2177)$ & $(0.4139)$ & $(0.1908)$ & $(0.0937)$ \\
\hline \multirow[t]{2}{*}{ RER } & $-1.3249 * * *$ & $-0.5305^{* * *}$ & -0.1369 & -0.0854 \\
\hline & $(0.1329)$ & $(0.0879)$ & $(0.1754)$ & $(0.0634)$ \\
\hline \multirow[t]{2}{*}{ IMR(kappa) } & -0.0400 & -0.4264 & $0.7251 * *$ & 0.2140 \\
\hline & $(0.8696)$ & $(0.4031)$ & $(0.3607)$ & $(0.2220)$ \\
\hline JSSE & 0.4780 & 0.6231 & 0.5872 & 0.0892 \\
\hline Upper regime $(\%)$ & $140 / 174$ & $52 / 174$ & $77 / 174$ & $63 / 174$ \\
\hline
\end{tabular}

Note: The instrumental variables for the model are first and twelfth lags of inflation gap, output gap and real exchange rate. Values in paranthesis are standard errors. *,**,*** denote significance at $1 \%, 5 \%$ and $10 \%$ significance levels. 
DENIZ, STENGOS, YAZGAN Taylor Rule Model for Turkey

Model 2:

$\begin{aligned} r_{t}-r_{t-1}^{*}= & I\left(q_{t} \leq \gamma\right)\left(\beta_{0}^{L}+\beta_{1}^{L}\left(r_{t-1}-r_{t-1}^{*}\right)+\beta_{2}^{L} E_{t}\left(\pi_{\text {end }}-\pi_{t}^{T}\right)+\beta_{3}^{L} \tilde{y}_{t}+\beta_{4}^{L} \text { rer }_{t}\right) \\ & +I\left(q_{t}>\gamma\right)\left(\beta_{0}^{H}+\beta_{1}^{H}\left(r_{t-1}-r_{t-1}^{*}\right)+\beta_{2}^{H} E_{t}\left(\pi_{\text {end }}-\pi_{t}^{T}\right)+\beta_{3}^{H} \tilde{y}_{t}+\beta_{4}^{H} r e r_{t}\right)+u_{t}\end{aligned}$

Table B. 4: Hansen (2000) for Model 2

\begin{tabular}{|c|c|c|c|c|}
\hline Threshold variable & inflation gap & output gap & rer & interest rate \\
\hline Threshold estimate & 0.0478 & -0.0240 & 4.5623 & 0.0662 \\
\hline 95\% C.I. & {$[0.0170,0.0574]$} & {$[0.034,0.0200]$} & {$[0.5622,4.5886]$} & {$[0.0061,0.0711]$} \\
\hline Regime 1 & $\tilde{\pi}_{t} \leq \gamma_{\tilde{\pi}}$ & $\tilde{y}_{t} \leq \gamma_{\tilde{y}}$ & $\operatorname{rer}_{t} \leq \gamma_{\text {rer }}$ & $i_{t} \leq \gamma_{i}$ \\
\hline \multirow[t]{2}{*}{ Constant } & $0.0724 * *$ & -0.0010 & $0.8232 * * *$ & $0.1362 * * *$ \\
\hline & $(0.0314)$ & $(0.0905)$ & $(0.2114)$ & $(0.0323)$ \\
\hline \multirow[t]{2}{*}{ Lagged LHS } & $0.9671 * * *$ & $0.9281 * * *$ & $0.1946^{*}$ & $0.9721 * * *$ \\
\hline & $(0.0089)$ & $(0.0226)$ & $(0.1134)$ & $(0.0123)$ \\
\hline \multirow[t]{2}{*}{ Inflation gap } & 0.0107 & 0.0097 & $0.5900 * * *$ & -0.0236 \\
\hline & $(0.0396)$ & $(0.0458)$ & $(0.2476)$ & $(0.0380)$ \\
\hline \multirow[t]{2}{*}{ Output gap } & $0.0501 * * *$ & 0.0492 & 0.1472 & $0.0477 * * *$ \\
\hline & $(0.0158)$ & $(0.0317)$ & $(0.1262)$ & $(0.0131)$ \\
\hline \multirow[t]{2}{*}{ RER } & $-0.0159 * * *$ & -0.0003 & $-0.1916 * * *$ & $-0.0294 * * *$ \\
\hline & $(0.0067)$ & $(0.0192)$ & $(0.0461)$ & $(0.0068)$ \\
\hline Regime 2 & $\tilde{\pi}_{t}>\gamma_{\pi}$ & $\tilde{y}_{t}>\gamma_{\tilde{y}}$ & rer $_{t}>\gamma_{\text {rer }}$ & $i_{t}>\gamma_{i}$ \\
\hline \multirow[t]{2}{*}{ Constant } & $0.1821^{* * *}$ & $0.1038^{* * *}$ & 0.0568 & $0.5861 * * *$ \\
\hline & $(0.0751)$ & $(0.0301)$ & $(0.0346)$ & $(0.0982)$ \\
\hline \multirow[t]{2}{*}{ Lagged LHS } & $0.9953 * * *$ & $0.9912 * * *$ & $0.9820 * * *$ & $0.7586 * * *$ \\
\hline & $(0.0703)$ & $(0.0088)$ & $(0.0072)$ & $(0.0513)$ \\
\hline \multirow[t]{2}{*}{ Inflation gap } & -0.2379 & $0.0821 * * *$ & $0.0630 * * *$ & 0.0656 \\
\hline & $(0.1725)$ & $(0.0347)$ & $(0.0254)$ & $(0.0632)$ \\
\hline \multirow[t]{2}{*}{ Output gap } & $0.0770 * *$ & 0.0189 & $0.0457 * * *$ & $0.1781 * * *$ \\
\hline & $(0.0372)$ & $(0.0266)$ & $(0.0125)$ & $(0.0517)$ \\
\hline \multirow[t]{2}{*}{ RER } & $-0.0352 * *$ & $-0.0227 * * *$ & $-0.0127 *$ & $-0.1204 * * *$ \\
\hline & $(0.0176)$ & $(0.0064)$ & $(0.0073)$ & $(0.0209)$ \\
\hline LM-test & 14.3985 & 13.0258 & 17.3548 & 21.7810 \\
\hline Bootstrap P-Value & 0.0330 & 0.0650 & 0.0050 & 0.0010 \\
\hline
\end{tabular}

Note:Values in paranthesis are standard errors. *,**,*** denote significance at $10 \%, 5 \%$ and $1 \%$ significance levels. 
Review of Economic Analysis 12 (2020) 167-202

Table B. 5: Structural regression model using GMM for Model 2

\begin{tabular}{|c|c|c|c|c|}
\hline $\begin{array}{l}\text { Threshold variable } \\
\text { Threshold estimate } \\
\text { 95\% C.I. }\end{array}$ & $\begin{array}{c}\text { inflation gap } \\
0.0106 \\
{[-0.0089,0.0487]}\end{array}$ & $\begin{array}{c}\text { output gap } \\
-0.0044 \\
{[-0.05,0.0458]}\end{array}$ & $\begin{array}{c}\text { rer } \\
4.6687 \\
{[4.5096,4.7878]}\end{array}$ & $\begin{array}{c}\text { interest rate } \\
0.0262 \\
{[-0.0713,0.0962]}\end{array}$ \\
\hline Regime 1 & $\tilde{\pi}_{t} \leq \gamma_{\tilde{\pi}}$ & $\tilde{y}_{t} \leq \gamma_{\tilde{y}}$ & $\mathrm{rer}_{t} \leq \gamma_{\text {rer }}$ & $i_{t} \leq \gamma_{i}$ \\
\hline Constant & $\begin{array}{l}0.5207^{*} \\
(0.2871)\end{array}$ & $\begin{array}{c}0.1438^{* * * *} \\
(0.0568)\end{array}$ & $\begin{array}{c}0.055 \\
(0.3633)\end{array}$ & $\begin{array}{c}0.5658 * * * \\
(0.1325)\end{array}$ \\
\hline Lagged LHS & $\begin{array}{c}0.9238 * * * \\
(0.0284)\end{array}$ & $\begin{array}{c}0.9328 * * * \\
(0.0277)\end{array}$ & $\begin{array}{c}1.0459 * * * \\
(0.0847)\end{array}$ & $\begin{array}{c}0.6539 * * * \\
(0.0885)\end{array}$ \\
\hline Inflation gap & $\begin{array}{c}0.2982 \\
(0.2892)\end{array}$ & $\begin{array}{l}-0.0577 \\
(0.0401)\end{array}$ & $\begin{array}{c}0.2789 \\
(0.2284)\end{array}$ & $\begin{array}{l}-0.0272 \\
(0.0535)\end{array}$ \\
\hline Output gap & $\begin{array}{c}0.0964 * * * \\
(0.0291)\end{array}$ & $\begin{array}{c}0.0976 * * * \\
(0.0314)\end{array}$ & $\begin{array}{c}0.0155 \\
(0.0324)\end{array}$ & $\begin{array}{l}-0.076^{*} \\
(0.0396)\end{array}$ \\
\hline RER & $\begin{array}{l}-0.0581 \\
(0.0459)\end{array}$ & $\begin{array}{c}-0.0283 * * * * \\
(0.0113)\end{array}$ & $\begin{array}{l}-0.0248 \\
(0.0915)\end{array}$ & $\begin{array}{c}-0.0683 * * * \\
(0.0154)\end{array}$ \\
\hline Regime 2 & $\tilde{\pi}_{t}>\gamma_{\pi}$ & $\tilde{y}_{t}>\gamma_{\tilde{y}}$ & $\operatorname{rer}_{t}>\gamma_{\text {rer }}$ & $i_{t}>\gamma_{i}$ \\
\hline Constant & $\begin{array}{c}-0.1384 \\
(0.1343)\end{array}$ & $\begin{array}{c}0.0263 \\
(0.0426)\end{array}$ & $\begin{array}{c}0.3589 \\
(0.4186)\end{array}$ & $\begin{array}{c}-0.1063 \\
(0.1235)\end{array}$ \\
\hline Lagged LHS & $\begin{array}{c}0.988 * * * \\
(0.0469)\end{array}$ & $\begin{array}{c}0.9632 * * * \\
(0.0204)\end{array}$ & $\begin{array}{c}0.9451 * * * \\
(0.0365)\end{array}$ & $\begin{array}{c}0.9421 * * * \\
(0.0437)\end{array}$ \\
\hline Inflation gap & $\begin{array}{c}0.2115^{* *} * \\
(0.1023)\end{array}$ & $\begin{array}{c}0.0837 * * * \\
(0.0356)\end{array}$ & $\begin{array}{c}0.0429 \\
(0.0445)\end{array}$ & $\begin{array}{c}0.0473 \\
(0.0294)\end{array}$ \\
\hline Output gap & $\begin{array}{c}0.0345 \\
(0.0224)\end{array}$ & $\begin{array}{l}-0.0002 \\
(0.064)\end{array}$ & $\begin{array}{c}0.0662 * * * \\
(0.0163)\end{array}$ & $\begin{array}{c}0.1667 * * * \\
(0.0439)\end{array}$ \\
\hline RER & $\begin{array}{c}-0.024 \\
(0.0122)\end{array}$ & $\begin{array}{l}-0.0083 \\
(0.0095)\end{array}$ & $\begin{array}{l}-0.0652 \\
(0.0732)\end{array}$ & $\begin{array}{l}-0.0357 \\
(0.0134)\end{array}$ \\
\hline \multicolumn{5}{|l|}{ Difference } \\
\hline Constant & $\begin{array}{l}0.6591^{*} \\
(0.3806)\end{array}$ & $\begin{array}{c}0.1176 \\
(0.0762)\end{array}$ & $\begin{array}{l}-0.3039 \\
(0.2606)\end{array}$ & $\begin{array}{c}0.6722^{* * * *} \\
(0.2427)\end{array}$ \\
\hline Lagged LHS & $\begin{array}{l}-0.0642 \\
(0.0489)\end{array}$ & $\begin{array}{l}-0.0304 \\
(0.0347)\end{array}$ & $\begin{array}{c}0.1008 \\
(0.0976)\end{array}$ & $\begin{array}{c}-0.2881 * * * \\
(0.1096)\end{array}$ \\
\hline Inflation gap & $\begin{array}{l}0.0866^{*} \\
(0.2984)\end{array}$ & $\begin{array}{c}-0.1414 * * * * \\
(0.052)\end{array}$ & $\begin{array}{c}0.236 \\
(0.2284)\end{array}$ & $\begin{array}{l}-0.0744 \\
(0.0619)\end{array}$ \\
\hline Output gap & $\begin{array}{l}0.0619^{*} \\
(0.0353)\end{array}$ & $\begin{array}{l}0.0978^{*} \\
(0.0525)\end{array}$ & $\begin{array}{l}-0.0507 \\
(0.0359)\end{array}$ & $\begin{array}{c}-0.2427 * * * \\
(0.0727)\end{array}$ \\
\hline RER & $\begin{array}{l}-0.0341 \\
(0.0453)\end{array}$ & $\begin{array}{c}-0.02 \\
(0.0155)\end{array}$ & $\begin{array}{c}0.0404 \\
(0.0493)\end{array}$ & $\begin{array}{l}-0.0326 \\
(0.0226)\end{array}$ \\
\hline IMR(kappa) & $\begin{array}{l}0.3098 \\
(0.216)\end{array}$ & $\begin{array}{c}0.0136 \\
(0.0439)\end{array}$ & $\begin{array}{l}-0.0697 \\
(0.0958)\end{array}$ & $\begin{array}{c}0.3401 * * * \\
(0.1025)\end{array}$ \\
\hline JSSE & 0.21542 & 0.50198 & 0.51518 & 0.061778 \\
\hline JSTAT & 4.0896 & 2.812 & 5.4897 & 8.5652 \\
\hline Upper regime $(\%)$ & 129 & 106 & 97 & $61 / 173$ \\
\hline
\end{tabular}

Note: The instrumental variables for the model are first and twelfth lags of inflation gap,

output gap and real exchange rate. Values in paranthesis are standard errors. *,**,***

denote significance at $10 \%, 5 \%$ and $1 \%$ significance levels. 
DENIZ, STENGOS, YAZGAN Taylor Rule Model for Turkey

Table B. 6: Structural regression model using Least Squares for Model 2

\begin{tabular}{|c|c|c|c|c|}
\hline Threshold variable & inflation gap & output gap & rer & interest rate \\
\hline Threshold estimate & 0.0247 & -0.025 & 4.5623 & 0.0262 \\
\hline 95\% C.I. & {$[-0.0089,0.0487]$} & {$[-0.05,0.0458]$} & {$[4.5096,4.7878]$} & {$[-0.0713,0.0962]$} \\
\hline Regime 1 & $\tilde{\pi}_{t} \leq \gamma_{\tilde{\pi}}$ & $\tilde{y}_{t} \leq \gamma_{\tilde{y}}$ & $r e r_{t} \leq \gamma_{r e r}$ & $i_{t} \leq \gamma_{i}$ \\
\hline \multirow[t]{2}{*}{ Constant } & $0.5347 * * *$ & 0.0029 & $0.8698 * * *$ & $0.2812^{* *}$ \\
\hline & $(0.2065)$ & $(0.0433)$ & $(0.2939)$ & $(0.1343)$ \\
\hline \multirow[t]{2}{*}{ Lagged LHS } & $0.9521 * * *$ & $0.9285^{* * *}$ & 0.2266 & $0.8506^{* * *}$ \\
\hline & $(0.0156)$ & $(0.0239)$ & $(0.2584)$ & $(0.0657)$ \\
\hline \multirow[t]{2}{*}{ Inflation gap } & $0.235 *$ & 0.0127 & 0.5967 & -0.0409 \\
\hline & $(0.1209)$ & $(0.0337)$ & $(0.4185)$ & $(0.0631)$ \\
\hline \multirow[t]{2}{*}{ Output gap } & $0.0607 * * *$ & $0.0517 * * *$ & 0.1517 & 0.0042 \\
\hline & $(0.0134)$ & $(0.0208)$ & $(0.1731)$ & $(0.0147)$ \\
\hline \multirow[t]{2}{*}{ RER } & -0.0359 & 0.0001 & $-0.2107 * * *$ & $-0.0427 * *$ \\
\hline & $(0.0267)$ & $(0.0108)$ & $(0.0684)$ & $(0.0192)$ \\
\hline Regime 2 & $\tilde{\pi}_{t}>\gamma_{\pi}$ & $\tilde{y}_{t}>\gamma_{\tilde{y}}$ & rer $_{t}>\gamma_{\text {rer }}$ & $i_{t}>\gamma_{i}$ \\
\hline \multirow[t]{2}{*}{ Constant } & -0.2012 & $0.0977 * * *$ & 0.2297 & 0.1403 \\
\hline & $(0.1281)$ & $(0.0366)$ & $(0.2220)$ & $(0.1041)$ \\
\hline \multirow[t]{2}{*}{ Lagged LHS } & $1.0344 * * *$ & $0.9913 * * *$ & $0.9828 * * *$ & $0.8827 * * *$ \\
\hline & $(0.014)$ & $(0.0102)$ & $(0.0091)$ & $(0.0297)$ \\
\hline \multirow[t]{2}{*}{ Inflation gap } & $0.2481 * * *$ & $0.0826 * * *$ & $0.0649 * *$ & $0.0752 * * *$ \\
\hline & $(0.0955)$ & $(0.0309)$ & $(0.0312)$ & $(0.0294)$ \\
\hline \multirow[t]{2}{*}{ Output gap } & $0.0427 * * *$ & 0.0212 & $0.0445^{* * *}$ & $0.0968 * * *$ \\
\hline & $(0.0128)$ & $(0.0262)$ & $(0.0102)$ & $(0.0175)$ \\
\hline \multirow[t]{2}{*}{ RER } & $-0.0386 * * *$ & $-0.0226^{* * *}$ & -0.0417 & $-0.0483 * * *$ \\
\hline & $(0.0083)$ & $(0.0071)$ & $(0.0384)$ & $(0.0141)$ \\
\hline \multicolumn{5}{|l|}{ Difference } \\
\hline \multirow[t]{2}{*}{ Constant } & $0.7359 * *$ & $-0.0948^{*}$ & $0.6401 * *$ & 0.1409 \\
\hline & $(0.3168)$ & $(0.0504)$ & $(0.3218)$ & $(0.2202)$ \\
\hline \multirow[t]{2}{*}{ Lagged LHS } & $-0.0823 * * *$ & $-0.0628 * * *$ & $-0.7563 * * *$ & -0.0322 \\
\hline & $(0.0209)$ & $(0.0261)$ & $(0.2582)$ & $(0.0744)$ \\
\hline \multirow[t]{2}{*}{ Inflation gap } & -0.0131 & -0.07 & 0.5318 & $-0.1161 *$ \\
\hline & $(0.0807)$ & $(0.0462)$ & $(0.4194)$ & $(0.0697)$ \\
\hline \multirow[t]{2}{*}{ Output gap } & 0.0181 & 0.0304 & 0.1072 & $-0.0926 * * *$ \\
\hline & $(0.0186)$ & $(0.033)$ & $(0.1735)$ & $(0.0251)$ \\
\hline \multirow[t]{2}{*}{ RER } & 0.0027 & $0.0227 *$ & $-0.169 * * *$ & 0.0055 \\
\hline & $(0.0275)$ & $(0.0129)$ & $(0.0647)$ & $(0.0264)$ \\
\hline \multirow[t]{2}{*}{ IMR(kappa) } & $0.4693 * * *$ & 0.0072 & -0.0517 & 0.1143 \\
\hline & $(0.1708)$ & $(0.0237)$ & $(0.0593)$ & $(0.0738)$ \\
\hline JSSE & 0.0072 & 0.0079 & 0.0062 & 0.0063 \\
\hline Upper regime (\%) & 86 & 142 & 149 & $61 / 173$ \\
\hline
\end{tabular}

Note: The instrumental variables for the model are first and twelfth lags of inflation gap, output gap and real exchange rate. Values in paranthesis are standard errors. ***,*** denote significance at $10 \%, 5 \%$ and $1 \%$ significance levels. 
Review of Economic Analysis 12 (2020) 167-202

\section{Model 3:}

$$
\begin{aligned}
\Delta i_{t}=I\left(q_{t} \leq \gamma\right)\left(\beta_{0}^{L}+\beta_{1}^{L}\left(E_{t} \pi_{\text {end }}-\pi_{t}^{T}\right)+\beta_{2}^{L} \tilde{u}_{t}+\beta_{3}^{L} r e r_{t}\right) \\
\\
+I\left(q_{t}>\gamma\right)\left(\beta_{0}^{H}+\beta_{1}^{H}\left(E_{t} \pi_{\text {end }}-\pi_{t}^{T}\right)+\beta_{2}^{H} \tilde{u}_{t}+\beta_{3}^{H} r e r_{t}\right)+u_{t}
\end{aligned}
$$

Table B. 7: Hansen (2000) for Model 3

\begin{tabular}{lcccc}
\hline Threshold variable & inflation gap & unemployment gap & rer & interest rate \\
\hline Threshold estimate & 0.0153 & -2.7803 & 4.7275 & -0.01 \\
95\% C.I. & {$[-0.0210,0.0781]$} & {$[-2.7803,2.5196]$} & {$[4.7123,4.7855]$} & {$[-0.0100,-0.0100]$} \\
\hline Regime 1 & $\pi \leq \gamma_{\pi}$ & $\pi \leq \gamma_{\tilde{y}}$ & $\pi \leq \gamma_{\text {rer }}$ & $\pi \leq \gamma_{i}$ \\
\hline Constant & -0.0784 & 1.0354 & $0.1593 * * *$ & 0.0055 \\
& $(0.2056)$ & $(1.7371)$ & $(0.0627)$ & $(0.0517)$ \\
Inflation gap & 0.0133 & 2.4238 & -0.0912 & 0.0206 \\
& $(0.1999)$ & $(1.5468)$ & $(0.0657)$ & $(0.0492)$ \\
Unemployment gap & 0.0018 & 0.0095 & $0.0017 * * *$ & -0.0004 \\
& $(0.0013)$ & $(0.0190)$ & $(0.0007)$ & $(0.0006)$ \\
RER & 0.0171 & -0.2128 & -0.0341 & -0.0040 \\
& $(0.0434)$ & $(0.3568)$ & $(0.0133)$ & $(0.0110)$ \\
\hline Regime 2 & $\pi>\gamma_{\pi}$ & $\pi>\gamma_{\tilde{y}}$ & $\pi>\gamma_{\text {rer }}$ & $\pi>\gamma_{i}$ \\
\hline Constant & $0.0778^{*}$ & $0.0703 *$ & 0.2264 & 0.0409 \\
& $(0.0412)$ & $(0.0388)$ & $(0.1964)$ & $(0.0271)$ \\
Inflation gap & 0.0123 & -0.0442 & 0.1075 & 0.0010 \\
& $(0.0637)$ & $(0.0475)$ & $(0.0841)$ & $(0.0369)$ \\
Unemployment gap & 0.0002 & 0.0005 & $-0.0032^{* * *}$ & 0.0002 \\
& $(0.0008)$ & $(0.0007)$ & $(0.0014)$ & $(0.0004)$ \\
RER & $-0.0169^{*}$ & $-0.0148^{*}$ & -0.0474 & -0.0077 \\
& $(0.0088)$ & $(0.0082)$ & $(0.0411)$ & $(0.0057)$ \\
\hline LM-test & 7.1054 & 3.99788 & 11.5222 & 71.8867 \\
Bootstrap P-Value & 0.606 & 0.958 & 0.092 & 0.000 \\
\hline \hline
\end{tabular}

Note:Values in paranthesis are standard errors. $* * *, * * *$ denote significance at $1 \%, 5 \%$ and $10 \%$ significance levels. 
DENIZ, STENGOS, YAZGAN Taylor Rule Model for Turkey

Table B. 8: Structural regression model using GMM for Model 3

\begin{tabular}{|c|c|c|c|c|}
\hline Threshold variable & inflation gap & unemployment gap & rer & interest rate \\
\hline Threshold estimate & 0.0113 & 2.12 & 4.7259 & -0.01 \\
\hline $95 \%$ confidence interval & {$[0.0068,0.0498]$} & {$[-1.88,2.32]$} & {$[4.5051,4.7923]$} & {$[-0.01,0.01]$} \\
\hline Regime 1 & $\pi \leq \gamma_{\pi}$ & $\pi \leq \gamma_{\tilde{y}}$ & $\pi \leq \gamma_{\text {rer }}$ & $\pi \leq \gamma_{i}$ \\
\hline \multirow[t]{2}{*}{ Constant } & -1.2924 & 0.0375 & 0.1213 & $-0.7524 * *$ \\
\hline & $(0.8312)$ & $(0.0354)$ & $(0.2287)$ & $(0.3724)$ \\
\hline \multirow[t]{2}{*}{ Inflation gap } & -0.423 & -0.0522 & -0.0332 & 0.0287 \\
\hline & $(0.4479)$ & $(0.0500)$ & $(0.0719)$ & $(0.0285)$ \\
\hline \multirow[t]{2}{*}{ Unemployment gap } & -0.0039 & 0.0008 & $0.0011^{*}$ & -0.0004 \\
\hline & $(0.0027)$ & $(0.0012)$ & $(0.0006)$ & $(0.0006)$ \\
\hline \multirow[t]{2}{*}{ RER } & $0.2809 * *$ & -0.0076 & -0.0248 & 0.0051 \\
\hline & $(0.1433)$ & $(0.0075)$ & $(0.0666)$ & $(0.0078)$ \\
\hline Regime 2 & $\pi>\gamma_{\pi}$ & $\pi>\gamma_{\tilde{y}}$ & $\pi>\gamma_{\text {rer }}$ & $\pi>\gamma_{i}$ \\
\hline \multirow[t]{2}{*}{ Constant } & 0.0309 & $0.435 * *$ & 0.4877 & $0.7152^{* *} *$ \\
\hline & $(0.2201)$ & $(0.2249)$ & $(0.5886)$ & $(0.3336)$ \\
\hline \multirow[t]{2}{*}{ Inflation gap } & 0.0512 & 0.0612 & 0.0926 & 0.0177 \\
\hline & $(0.1732)$ & $(0.2109)$ & $(0.0726)$ & $(0.0401)$ \\
\hline \multirow[t]{2}{*}{ Unemployment gap } & 0.0002 & 0.0001 & -0.0021 & -0.0002 \\
\hline & $(0.0009)$ & $(0.013)$ & $(0.0016)$ & $(0.0005)$ \\
\hline \multirow[t]{2}{*}{ RER } & $-0.017 * *$ & $-0.0935^{* *}$ & -0.1034 & -0.0016 \\
\hline & $(0.0084)$ & $(0.0467)$ & $(0.1072)$ & $(0.0067)$ \\
\hline \multicolumn{5}{|l|}{ Difference } \\
\hline \multirow[t]{2}{*}{ Constant } & -1.3233 & $-0.3975^{*}$ & -0.3664 & $-1.4677 * *$ \\
\hline & $(1.0026)$ & $(0.2274)$ & $(0.3966)$ & $(0.705)$ \\
\hline \multirow[t]{2}{*}{ Inflation gap } & -0.4742 & -0.1134 & -0.1258 & 0.011 \\
\hline & $(0.3456)$ & $(0.2165)$ & $(0.1065)$ & $(0.0459)$ \\
\hline \multirow[t]{2}{*}{ Unemployment gap } & -0.0041 & 0.0007 & $0.0032 *$ & -0.0002 \\
\hline & $(0.0027)$ & $(0.0127)$ & $(0.0017)$ & $(0.0008)$ \\
\hline \multirow[t]{2}{*}{ RER } & $0.2979 * *$ & $0.0859 *$ & 0.0785 & 0.0067 \\
\hline & $(0.1425)$ & $(0.0474)$ & $(0.058)$ & $(0.0091)$ \\
\hline \multirow[t]{2}{*}{ IMR(kappa) } & 0.0596 & 0.0037 & 0.0088 & $-0.889 * *$ \\
\hline & $(0.2799)$ & $(0.0053)$ & $(0.1089)$ & $(0.4438)$ \\
\hline JSSE & 0.013392 & 0.013476 & 0.012998 & 0.0049152 \\
\hline J stat & 13.5672 & 4.81 & 3.0631 & 2.5171 \\
\hline Upper regime (\%) & $125 / 149$ & 22 & 45 & 110 \\
\hline
\end{tabular}

Note: The instrumental variables for the model are first and twelfth lags of inflation gap,

output gap and real exchange rate. Values in paranthesis are standard errors. ***,***

denote significance at $1 \%, 5 \%$ and $10 \%$ significance levels. 
Review of Economic Analysis 12 (2020) 167-202

Table B. 9: Structural regression model using Least Squares for Model 3

\begin{tabular}{|c|c|c|c|c|}
\hline Threshold variable & inflation gap & unemployment gap & rer & interest rate \\
\hline Threshold estimate & 0.0153 & 2.12 & 4.7276 & -0.01 \\
\hline $95 \%$ confidence interval & {$[0.0068,0.0498]$} & {$[-1.88,2.32]$} & {$[4.5051,4.7923]$} & {$[-0.01,0.01]$} \\
\hline Regime 1 & $\pi \leq \gamma_{\pi}$ & $\pi \leq \gamma_{\tilde{y}}$ & $\pi \leq \gamma_{r e r}$ & $\pi \leq \gamma_{i}$ \\
\hline \multirow[t]{2}{*}{ Constant } & 0.1519 & 0.0382 & $0.2028 * *$ & $-0.9813 * *$ \\
\hline & $(0.2577)$ & $(0.0348)$ & $(0.0921)$ & $(0.4284)$ \\
\hline \multirow[t]{2}{*}{ Inflation gap } & 0.1741 & -0.0277 & $-0.0881^{*}$ & $0.049^{*}$ \\
\hline & $(0.2584)$ & $(0.0443)$ & $(0.0501)$ & $(0.029)$ \\
\hline \multirow[t]{2}{*}{ Unemployment gap } & 0.0017 & 0.001 & $0.0016^{* * * *}$ & -0.0008 \\
\hline & $(0.0017)$ & $(0.0011)$ & $(0.0007)$ & $(0.0007)$ \\
\hline \multirow[t]{2}{*}{ RER } & 0.0068 & -0.0079 & $-0.0473^{*}$ & 0.0043 \\
\hline & $(0.037)$ & $(0.0074)$ & $(0.0257)$ & $(0.0085)$ \\
\hline Regime 2 & $\pi>\gamma_{\pi}$ & $\pi>\gamma_{\tilde{y}}$ & $\pi>\gamma_{\text {rer }}$ & $\pi>\gamma_{i}$ \\
\hline \multirow[t]{2}{*}{ Constant } & -0.1005 & $0.4325^{* *}$ & 0.2983 & $0.935 * *$ \\
\hline & $(0.1659)$ & $(0.212)$ & $(0.1923)$ & $(0.3872)$ \\
\hline \multirow[t]{2}{*}{ Inflation gap } & 0.1191 & 0.0058 & 0.1029 & 0.0367 \\
\hline & $(0.1079)$ & $(0.1852)$ & $(0.0682)$ & $(0.0357)$ \\
\hline \multirow[t]{2}{*}{ Unemployment gap } & 0.0003 & -0.0024 & $-0.0032 * * *$ & -0.0001 \\
\hline & $(0.0009)$ & $(0.0119)$ & $(0.0012)$ & $(0.0005)$ \\
\hline \multirow[t]{2}{*}{ RER } & $-0.0182 * *$ & $-0.0913 * *$ & -0.0586 & 0.0002 \\
\hline & $(0.0076)$ & $(0.0459)$ & $(0.0368)$ & $(0.0063)$ \\
\hline \multicolumn{5}{|l|}{ Difference } \\
\hline \multirow{2}{*}{ Constant } & 0.2524 & $-0.3943 *$ & -0.0956 & $-1.9163 * *$ \\
\hline & $(0.3947)$ & $(0.2149)$ & $(0.1689)$ & $(0.8145)$ \\
\hline \multirow[t]{2}{*}{ Inflation gap } & 0.055 & -0.0336 & $-0.191 * *$ & 0.0122 \\
\hline & $(0.2267)$ & $(0.1900)$ & $(0.0849)$ & $(0.0439)$ \\
\hline \multirow[t]{2}{*}{ Output gap } & 0.0014 & 0.0034 & $0.0048 * * *$ & -0.0006 \\
\hline & $(0.0019)$ & $(0.0117)$ & $(0.0014)$ & $(0.0009)$ \\
\hline \multirow[t]{2}{*}{ RER } & 0.025 & $0.0834 *$ & 0.0114 & 0.004 \\
\hline & $(0.0379)$ & $(0.0465)$ & $(0.0354)$ & $(0.0093)$ \\
\hline \multirow[t]{2}{*}{ IMR(kappa) } & 0.2298 & 0.0044 & -0.0237 & $-1.1781 * *$ \\
\hline & $(0.2023)$ & $(0.0047)$ & $(0.0420)$ & $(0.5091)$ \\
\hline JSSE & 0.0131 & 0.01338 & 0.0126 & 0.0048 \\
\hline Upper regime $(\%)$ & $117 / 149$ & 22 & 43 & 110 \\
\hline
\end{tabular}

Note: The instrumental variables for the model are first and twelfth lags of inflation gap, output gap and real exchange rate. Values in paranthesis are standard errors. *,**,*** denote significance at $1 \%, 5 \%$ and $10 \%$ significance levels. 
DENIZ, STENGOS, YAZGAN Taylor Rule Model for Turkey

\section{Model 4:}

$$
\begin{aligned}
\Delta i_{t}=I\left(q_{t} \leq \gamma\right)\left(\beta_{0}^{L}+\beta_{1}^{L}\left(\pi_{t}-\pi_{t}^{T}\right)\right. & \left.+\beta_{2}^{L} \tilde{y}_{t}+\beta_{3}^{L} \text { rer }_{t}\right) \\
& +I\left(q_{t}>\gamma\right)\left(\beta_{0}^{H}+\beta_{1}^{H}\left(\pi_{t}-\pi_{t}^{T}\right)+\beta_{2}^{H} \tilde{y}_{t}+\beta_{3}^{H} \text { rer }_{t}\right)+u_{t}
\end{aligned}
$$

Table B. 10: Hansen (2000) for Model 4

\begin{tabular}{lcccc}
\hline Threshold variable & inflation gap & output gap & rer & interest rate \\
\hline Threshold estimate & 0.0515 & -0.0364 & 4.4526 & -0.01 \\
95\% C.I. & {$[-0.0213,0.0713]$} & {$[-0.1150,0.0137]$} & {$[4.4445,4.7258]$} & {$[-0.010,-0.0100]$} \\
\hline Regime 1 & $\pi \leq \gamma_{\pi}$ & $\pi \leq \gamma_{\tilde{y}}$ & $\pi \leq \gamma_{\text {rer }}$ & $\pi \leq \gamma_{i}$ \\
\hline Constant & 0.0332 & -0.1987 & -0.7920 & 0.0248 \\
& $(0.0457)$ & $(0.1610)$ & $(1.2276)$ & $(0.0472)$ \\
Inflation gap & $0.0896^{* * *}$ & 0.1155 & 0.3875 & -0.0060 \\
& $(0.0376)$ & $(0.0847)$ & $(0.2837)$ & $(0.0320)$ \\
Output gap & 0.0059 & $0.1439^{* * *}$ & -1.5414 & 0.0055 \\
& $(0.0198)$ & $(0.0545)$ & $(0.9925)$ & $(0.0179)$ \\
RER & -0.0076 & 0.0445 & 0.1764 & -0.0080 \\
& $(0.0097)$ & $(0.0342)$ & $(0.2772)$ & $(0.0101)$ \\
\hline Regime 2 & $\pi>\gamma_{\pi}$ & $\pi>\gamma_{\tilde{y}}$ & $\pi>\gamma_{r e r}$ & $\pi>\gamma_{i}$ \\
\hline Constant & 0.0467 & 0.0588 & 0.0545 & $0.0509 * *$ \\
& $(0.0525)$ & $(0.0355)$ & $(0.0392)$ & $(0.0240)$ \\
Inflation gap & $0.5465 * * *$ & $0.1050^{* * *}$ & $0.0749 * * *$ & $0.0577^{* * *}$ \\
& $(0.1494)$ & $(0.0314)$ & $(0.0288)$ & $(0.0215)$ \\
Output gap & 0.0554 & 0.0192 & 0.0157 & -0.0050 \\
& $(0.0457)$ & $(0.0309)$ & $(0.0181)$ & $(0.0148)$ \\
RER & -0.0174 & $-0.0134 *$ & -0.0121 & $-0.0103^{* *}$ \\
& $(0.0110)$ & $(0.0076)$ & $(0.0084)$ & $(0.0051)$ \\
\hline LM-test & 5.7308 & 9.4076 & 8.5442 & 70.7282 \\
Bootstrap P-Value & 0.86 & 0.272 & 0.426 & 0 \\
\hline \hline
\end{tabular}

Note:Values in paranthesis are standard errors. $* * *, * * *$ denote significance at $1 \%, 5 \%$ and $10 \%$ significance levels. 
Review of Economic Analysis 12 (2020) 167-202

Table B. 11: Structural regression model using GMM for Model 4

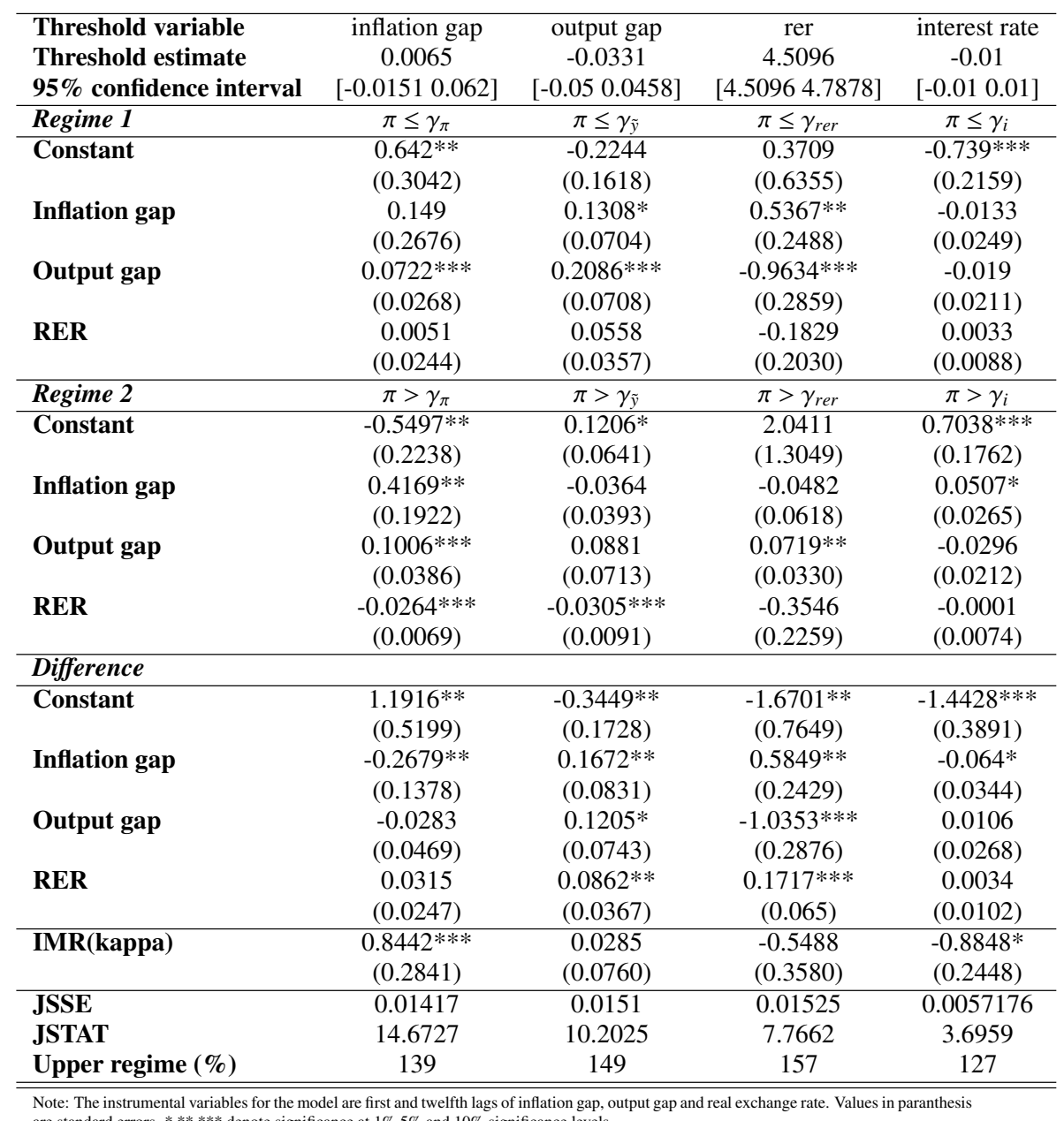

Note: The instrumental variables for the model are first and twelfth lags of inflation gap, output gap and real exchange rate. Values in paranthesis 
DENIZ, STENGOS, YAZGAN Taylor Rule Model for Turkey

Table B. 12: Structural regression model using Least Squares for Model 4

\begin{tabular}{|c|c|c|c|c|}
\hline Threshold variable & inflation gap & output gap & rer & interest rate \\
\hline Threshold estimate & 0.0187 & -0.0364 & 4.5194 & -0.01 \\
\hline 95\% C.I. & {$[-0.0151,0.062]$} & {$[-0.05,0.0458]$} & {$[4.5096,4.7878]$} & {$[-0.01,0.01]$} \\
\hline Regime 1 & $\pi \leq \gamma_{\pi}$ & $\pi \leq \gamma_{\tilde{y}}$ & $\pi \leq \gamma_{\text {rer }}$ & $\pi \leq \gamma_{i}$ \\
\hline \multirow{2}{*}{ Constant } & $1.051 * * *$ & $-0.2312^{*}$ & -0.0992 & $-0.8155^{* * *}$ \\
\hline & $(0.2243)$ & $(0.1423)$ & $(0.2530)$ & $(0.2313)$ \\
\hline \multirow[t]{2}{*}{ Inflation gap } & $0.6507 * * *$ & 0.0861 & $0.3298 *$ & 0.0068 \\
\hline & $(0.1525)$ & $(0.0762)$ & $(0.1832)$ & $(0.0206)$ \\
\hline \multirow[t]{2}{*}{ Output gap } & $0.0794 * * *$ & $0.1234 * *$ & $-0.5704 * * *$ & -0.0145 \\
\hline & $(0.0191)$ & $(0.0526)$ & $(0.2226)$ & $(0.0137)$ \\
\hline \multirow[t]{2}{*}{ RER } & $-0.0309 * * *$ & 0.0415 & 0.0132 & 0.0004 \\
\hline & $(0.0125)$ & $(0.0315)$ & $(0.0572)$ & $(0.0081)$ \\
\hline Regime 2 & $\pi>\gamma_{\pi}$ & $\pi>\gamma_{\tilde{y}}$ & $\pi>\gamma_{\text {rer }}$ & $\pi>\gamma_{i}$ \\
\hline \multirow[t]{2}{*}{ Constant } & $-0.8515 * * *$ & $0.1074 *$ & 0.1584 & $0.7915 * * *$ \\
\hline & $(0.1966)$ & $(0.0554)$ & $(0.1297)$ & $(0.1996)$ \\
\hline \multirow[t]{2}{*}{ Inflation gap } & $0.7117 * * *$ & $0.1007 * * *$ & $0.0743 * * *$ & $0.0793 * * *$ \\
\hline & $(0.1308)$ & $(0.0295)$ & $(0.0280)$ & $(0.0223)$ \\
\hline \multirow[t]{2}{*}{ Output gap } & 0.0235 & 0.001 & 0.0151 & $-0.0252 *$ \\
\hline & $(0.0285)$ & $(0.0301)$ & $(0.018)$ & $(0.0133)$ \\
\hline \multirow[t]{2}{*}{ RER } & $-0.0172 * * *$ & $-0.0143 *$ & -0.0289 & -0.0002 \\
\hline & $(0.005)$ & $(0.0077)$ & $(0.0222)$ & $(0.0063)$ \\
\hline \multicolumn{5}{|l|}{ Difference } \\
\hline \multirow[t]{2}{*}{ Constant } & $1.9025 * * *$ & $-0.3386^{* *}$ & -0.2576 & $-1.607 * * *$ \\
\hline & $(0.4169)$ & $(0.1514)$ & $(0.2581)$ & $(0.4287)$ \\
\hline \multirow[t]{2}{*}{ Inflation gap } & -0.0611 & -0.0145 & 0.2554 & $-0.0725^{* *}$ \\
\hline & $(0.0695)$ & $(0.0801)$ & $(0.1855)$ & $(0.0298)$ \\
\hline \multirow[t]{2}{*}{ Output gap } & $0.0559 *$ & $0.1224 * *$ & $-0.5856^{* * *}$ & 0.0107 \\
\hline & $(0.0323)$ & $(0.0573)$ & $(0.2233)$ & $(0.0186)$ \\
\hline \multirow[t]{2}{*}{ RER } & -0.0137 & $0.0558 *$ & 0.0421 & 0.0007 \\
\hline & $(0.013)$ & $(0.0322)$ & $(0.0544)$ & $(0.0095)$ \\
\hline \multirow[t]{2}{*}{ IMR(kappa) } & $1.1508 * * *$ & -0.057 & -0.0367 & $-0.9959 * * *$ \\
\hline & $(0.2536)$ & $(0.0484)$ & $(0.0394)$ & $(0.2688)$ \\
\hline JSSE & 0.0076 & 0.0145 & 0.0148 & 0.0053 \\
\hline Upper regime (\%) & $119 / 174$ & 151 & 155 & 127 \\
\hline
\end{tabular}

Note: The instrumental variables for the model are first and twelfth lags of inflation gap, output gap and real exchange rate. Values in paranthesis are standard errors. *,****** denote significance at $1 \%, 5 \%$ and $10 \%$ significance levels. 
Review of Economic Analysis 12 (2020) 167-202

\section{Model 5:}

$$
\begin{aligned}
\Delta r_{t}=I\left(q_{t} \leq \gamma\right)\left(\beta_{0}^{L}+\beta_{1}^{L}\left(E_{t} \pi_{\text {end }}-\pi_{t}^{T}\right)+\beta_{2}^{L} \tilde{y}_{t}+\beta_{3}^{L} r e r_{t}\right) \\
\quad+I\left(q_{t}>\gamma\right)\left(\beta_{0}^{H}+\beta_{1}^{H}\left(E_{t} \pi_{\text {end }}-\pi_{t}^{T}\right)+\beta_{2}^{H} \tilde{y}_{t}+\beta_{3}^{H} r e r_{t}\right)+u_{t}
\end{aligned}
$$

Table B. 13: Hansen (2000) for Model 5

\begin{tabular}{lcccc}
\hline Threshold variable & inflation gap & output gap & rer & interest rate \\
\hline Threshold estimate & 0.0690 & -0.0327 & 4.5859 & 0.0023 \\
95\% C.I. & {$[-0.0242,0.0713]$} & {$[-0.1150,0.0630]$} & {$[4.4445,4.8367]$} & $0.0009,0.0032]$ \\
\hline Regime 1 & $\pi \leq \gamma_{\pi}$ & $\pi \leq \gamma_{\tilde{y}}$ & $\pi \leq \gamma_{\text {rer }}$ & $\pi \leq \gamma_{i}$ \\
\hline Constant & $0.0681^{*}$ & 0.1149 & $0.3859^{*}$ & 0.0286 \\
& $(0.0395)$ & $(0.1577)$ & $(0.2329)$ & $(0.0297)$ \\
Inflation gap & -0.0163 & -0.0552 & $-0.3646^{* * *}$ & -0.0292 \\
& $(0.0320)$ & $(0.0671)$ & $(0.1525)$ & $(0.0236)$ \\
Output gap & $0.0398^{* *}$ & -0.0481 & $0.4433^{* * *}$ & $0.0379^{* * *}$ \\
& $(0.0193)$ & $(0.0502)$ & $(0.1861)$ & $(0.0155)$ \\
RER & $-0.0146^{*}$ & -0.0266 & -0.0819 & -0.0072 \\
& $(0.0084)$ & $(0.0336)$ & $(0.0505)$ & $(0.0063)$ \\
\hline Regime 2 & $\pi>\gamma_{\pi}$ & $\pi>\gamma_{\tilde{y}}$ & $\pi>\gamma_{\text {rer }}$ & $\pi>\gamma_{i}$ \\
\hline Constant & $0.2212^{* *}$ & 0.0526 & 0.0596 & $0.1037^{* * *}$ \\
& $(0.1010)$ & $(0.0380)$ & $(0.0570)$ & $(0.0412)$ \\
Inflation gap & $-1.1258^{* * *}$ & -0.0522 & -0.0130 & -0.0095 \\
& $(0.3682)$ & $(0.0346)$ & $(0.0325)$ & $(0.0370)$ \\
Output gap & 0.0863 & -0.0019 & $0.0364^{*}$ & 0.0388 \\
& $(0.1619)$ & $(0.0338)$ & $(0.0194)$ & $(0.0235)$ \\
RER & -0.0293 & -0.0108 & -0.0128 & $-0.0199^{* *}$ \\
& $(0.0203)$ & $(0.0081)$ & $(0.0121)$ & $(0.0088)$ \\
\hline LM-test & 7.0772 & 11.3613 & 5.8068 & 89.6762 \\
Bootstrap P-Value & 0.6660 & 0.1050 & 0.8450 & 0.0000 \\
\hline \hline
\end{tabular}

Note:Values in paranthesis are standard errors. $* * *, * * *$ denote significance at $1 \%, 5 \%$ and $10 \%$ significance levels. 
DENIZ, STENGOS, YAZGAN Taylor Rule Model for Turkey

Table B. 14: Structural regression model using GMM for Model 5

\begin{tabular}{|c|c|c|c|c|}
\hline $\begin{array}{l}\text { Threshold variable } \\
\text { Threshold estimate } \\
\text { 95\% C.I. }\end{array}$ & $\begin{array}{c}\text { inflation gap } \\
0.0328 \\
{[-0.0151,0.062]}\end{array}$ & $\begin{array}{c}\text { output gap } \\
-0.0331 \\
{[-0.05,0.0458]}\end{array}$ & $\begin{array}{c}\text { rer } \\
4.5985 \\
{[4.5985,4.5985]}\end{array}$ & $\begin{array}{c}\text { interest rate } \\
0.0017 \\
{[-0.013,0.0118]}\end{array}$ \\
\hline Regime 1 & $\pi \leq \gamma_{\pi}$ & $\pi \leq \gamma_{\tilde{y}}$ & $\pi \leq \gamma_{\text {rer }}$ & $\pi \leq \gamma_{i}$ \\
\hline Constant & $\begin{array}{c}-1.0342 * * * \\
(0.3436)\end{array}$ & $\begin{array}{c}0.0878 \\
(0.1525)\end{array}$ & $\begin{array}{c}0.8231 * * \\
(0.3628)\end{array}$ & $\begin{array}{c}-0.5665^{*} \\
(0.3105)\end{array}$ \\
\hline Inflation gap & $\begin{array}{c}-0.644 * * \\
(0.2965)\end{array}$ & $\begin{array}{c}-0.0732 \\
(0.0753)\end{array}$ & $\begin{array}{c}0.1343 \\
(0.0866)\end{array}$ & $\begin{array}{c}-0.0238 \\
(0.0271)\end{array}$ \\
\hline Output gap & $\begin{array}{l}-0.0227 \\
(0.0339)\end{array}$ & $\begin{array}{l}-0.0759 \\
(0.0730)\end{array}$ & $\begin{array}{l}0.2189 * \\
(0.1294)\end{array}$ & $\begin{array}{c}0.0137 \\
(0.0196)\end{array}$ \\
\hline RER & $\begin{array}{c}0.0083 \\
(0.0124)\end{array}$ & $\begin{array}{l}-0.0165 \\
(0.0286)\end{array}$ & $\begin{array}{c}-0.262 * * * * \\
(0.0937)\end{array}$ & $\begin{array}{c}-0.0047 \\
(0.0061)\end{array}$ \\
\hline Regime 2 & $\pi>\gamma_{\pi}$ & $\pi>\gamma_{\tilde{y}}$ & $\pi>\gamma_{\text {rer }}$ & $\pi>\gamma_{i}$ \\
\hline Constant & $\begin{array}{c}1.0478^{* * * *} \\
(0.3328)\end{array}$ & $\begin{array}{l}-0.0473 \\
(0.0635)\end{array}$ & $\begin{array}{c}1.8573 * * * \\
(0.3943)\end{array}$ & $\begin{array}{c}0.6572 * * \\
(0.2990)\end{array}$ \\
\hline Inflation gap & $\begin{array}{c}-0.7206^{* *} \\
(0.2999)\end{array}$ & $\begin{array}{c}0.0494 \\
(0.0404)\end{array}$ & $\begin{array}{c}0.1187 * * \\
(0.0493)\end{array}$ & $\begin{array}{c}-0.0532 \\
(0.0433)\end{array}$ \\
\hline Output gap & $\begin{array}{l}-0.0383 \\
(0.0355)\end{array}$ & $\begin{array}{l}-0.0574 \\
(0.0647)\end{array}$ & $\begin{array}{l}-0.0138 \\
(0.0354)\end{array}$ & $\begin{array}{c}0.0421 * * \\
(0.0173)\end{array}$ \\
\hline RER & $\begin{array}{l}-0.0014 \\
(0.0098)\end{array}$ & $\begin{array}{c}0.0052 \\
(0.0092)\end{array}$ & $\begin{array}{c}-0.3222 * * * \\
(0.0688)\end{array}$ & $\begin{array}{l}-0.0131 \\
(0.0087)\end{array}$ \\
\hline \multicolumn{5}{|l|}{ Difference } \\
\hline Constant & $\begin{array}{c}-2.0820 * * * \\
(0.6727)\end{array}$ & $\begin{array}{c}0.1352 \\
(0.1832)\end{array}$ & $\begin{array}{c}-1.0343 * * * \\
(0.2578)\end{array}$ & $\begin{array}{c}-1.2237 * * \\
(0.6077)\end{array}$ \\
\hline Inflation gap & $\begin{array}{c}0.0766 \\
(0.1279)\end{array}$ & $\begin{array}{l}-0.1226 \\
(0.0873)\end{array}$ & $\begin{array}{c}0.0156 \\
(0.0991)\end{array}$ & $\begin{array}{c}0.0294 \\
(0.0482)\end{array}$ \\
\hline Output gap & $\begin{array}{c}0.0156 \\
(0.0482)\end{array}$ & $\begin{array}{l}-0.0185 \\
(0.0715)\end{array}$ & $\begin{array}{l}0.2327^{*} \\
(0.1350)\end{array}$ & $\begin{array}{l}-0.0284 \\
(0.0262)\end{array}$ \\
\hline RER & $\begin{array}{c}0.0097 \\
(0.0154)\end{array}$ & $\begin{array}{l}-0.0217 \\
(0.0299)\end{array}$ & $\begin{array}{c}0.0602 \\
(0.0533)\end{array}$ & $\begin{array}{c}0.0084 \\
(0.0108)\end{array}$ \\
\hline IMR(kappa) & $\begin{array}{c}-1.2758 * * * \\
(0.4171)\end{array}$ & $\begin{array}{c}0.0288 \\
(0.0727)\end{array}$ & $\begin{array}{c}-0.4709 * * * \\
(0.0984)\end{array}$ & $\begin{array}{l}-0.7326^{*} \\
(0.3905)\end{array}$ \\
\hline JSSE & 0.0166 & 0.0162 & 0.0162 & 0.0077 \\
\hline JSTAT & 6.6234 & 14.8725 & 14.0112 & 3.4198 \\
\hline Upper regime $(\%)$ & 78 & 149 & 137 & $61 / 174$ \\
\hline
\end{tabular}

Note: The instrumental variables for the model are first and twelfth lags of inflation gap, output gap and real exchange rate. Values in paranthesis are standard errors. *,****** denote significance at $1 \%, 5 \%$ and $10 \%$ significance levels. 
Review of Economic Analysis 12 (2020) 167-202

Table B. 15: Structural regression model using Least Squares for Model 5

\begin{tabular}{|c|c|c|c|c|}
\hline Threshold variable & inflation gap & output gap & rer & interest rate \\
\hline Threshold estimate & 0.0167 & -0.0331 & 4.586 & 0.0015 \\
\hline 95\% C.I. & {$[-0.0151,0.062]$} & {$[-0.05,0.0458]$} & {$[4.5096,4.7878]$} & {$[-0.013,0.0118]$} \\
\hline Regime 1 & $\pi \leq \gamma_{\pi}$ & $\pi \leq \gamma_{\tilde{y}}$ & $\pi \leq \gamma_{\text {rer }}$ & $\pi \leq \gamma_{i}$ \\
\hline \multirow[t]{2}{*}{ Constant } & $-0.7653 * * *$ & 0.1743 & $0.4722^{*}$ & $-0.7556^{* *}$ \\
\hline & $(0.2353)$ & $(0.1309)$ & $(0.2511)$ & $(0.3749)$ \\
\hline \multirow[t]{2}{*}{ Inflation gap } & $-0.4063^{* *}$ & -0.0132 & $-0.3409 * *$ & $-0.0666^{* *}$ \\
\hline & $(0.1737)$ & $(0.0518)$ & $(0.1612)$ & $(0.0276)$ \\
\hline \multirow[t]{2}{*}{ Output gap } & -0.0088 & -0.0138 & $0.4578 *$ & $0.0341 * * *$ \\
\hline & $(0.0202)$ & $(0.0404)$ & $(0.2498)$ & $(0.0126)$ \\
\hline \multirow[t]{2}{*}{ RER } & $0.0353 * *$ & -0.021 & $-0.1111 *$ & -0.0058 \\
\hline & $(0.0153)$ & $(0.0272)$ & $(0.0612)$ & $(0.0056)$ \\
\hline Regime 2 & $\pi>\gamma_{\pi}$ & $\pi>\gamma_{\tilde{y}}$ & $\pi>\gamma_{\text {rer }}$ & $\pi>\gamma_{i}$ \\
\hline \multirow[t]{2}{*}{ Constant } & $0.6796 * * *$ & -0.0358 & 0.2566 & $0.8774 * * *$ \\
\hline & $(0.2158)$ & $(0.0522)$ & $(0.2579)$ & $(0.3402)$ \\
\hline \multirow[t]{2}{*}{ Inflation gap } & $-0.4832 * * *$ & -0.0466 & -0.0102 & -0.0352 \\
\hline & $(0.1529)$ & $(0.0309)$ & $(0.0294)$ & $(0.0301)$ \\
\hline \multirow[t]{2}{*}{ Output gap } & 0.0408 & 0.0368 & $0.0349 * *$ & $0.0324 * *$ \\
\hline & $(0.027)$ & $(0.0299)$ & $(0.0162)$ & $(0.0153)$ \\
\hline \multirow[t]{2}{*}{ RER } & $-0.0143^{*}$ & -0.0095 & -0.0457 & $-0.0185^{*}$ \\
\hline & $(0.0080)$ & $(0.0084)$ & $(0.0443)$ & $(0.0103)$ \\
\hline \multicolumn{5}{|l|}{ Difference } \\
\hline \multirow[t]{2}{*}{ Constant } & $-1.4449 * * *$ & 0.2101 & 0.2156 & $-1.6331 * *$ \\
\hline & $(0.4442)$ & $(0.1466)$ & $(0.2638)$ & $(0.7137)$ \\
\hline \multirow[t]{2}{*}{ Inflation gap } & 0.0769 & 0.0334 & $-0.3306 * *$ & -0.0314 \\
\hline & $(0.0919)$ & $(0.0593)$ & $(0.1629)$ & $(0.0354)$ \\
\hline \multirow[t]{2}{*}{ Output gap } & $-0.0495^{*}$ & -0.0507 & $0.4228 *$ & 0.0017 \\
\hline & $(0.0302)$ & $(0.0493)$ & $(0.2507)$ & $(0.0203)$ \\
\hline \multirow[t]{2}{*}{ RER } & $0.0497 * * *$ & -0.0115 & -0.0653 & 0.0126 \\
\hline & $(0.0173)$ & $(0.0285)$ & $(0.0495)$ & $(0.0111)$ \\
\hline \multirow[t]{2}{*}{ IMR(kappa) } & $-0.7575 * * *$ & $0.1059 * *$ & -0.0583 & $-0.9777 * *$ \\
\hline & $(0.2839)$ & $(0.0440)$ & $(0.0703)$ & $(0.4651)$ \\
\hline JSSE & 0.0132 & 0.0161 & 0.0162 & 0.0072 \\
\hline Upper regime $(\%)$ & 123 & 149 & 146 & $63 / 174$ \\
\hline
\end{tabular}

Note: The instrumental variables for the model are first and twelfth lags of inflation gap, output gap and real exchange rate. Values in paranthesis are standard errors. *,**,*** denote significance at $1 \%, 5 \%$ and $10 \%$ significance levels. 
DENIZ, STENGOS, YAZGAN Taylor Rule Model for Turkey

\section{Model 6:}

$$
\begin{aligned}
\Delta i_{t}=I\left(q_{t} \leq \gamma\right)\left(\beta_{0}^{L}+\beta_{1}^{L}\left(E_{t} \pi_{\text {end }}-\pi_{t}^{T}\right)+\beta_{2}^{L} \tilde{y}_{t}+\beta_{3}^{L} x_{r v o l}\right) \\
\\
\quad+I\left(q_{t}>\gamma\right)\left(\beta_{0}^{H}+\beta_{1}^{H}\left(E_{t} \pi_{\text {end }}-\pi_{t}^{T}\right)+\beta_{2}^{H} \tilde{y}_{t}+\beta_{3}^{H} x r v o l_{t}\right)+u_{t}
\end{aligned}
$$

Table B. 16: Hansen (2000) for Model 6

\begin{tabular}{lcccc}
\hline Threshold variable & inflation gap & output gap & xrvol & interest rate \\
\hline Threshold estimate & -0.002 & -0.115 & 0.0271 & 167 \\
95\% C.I. & {$[-0.0169,0.0685]$} & {$[-0.1150,0.0692]$} & {$[0.0137,0.0722]$} & {$[6.0000,168.0000]$} \\
\hline Regime 1 & $\pi \leq \gamma_{\pi}$ & $\pi \leq \gamma_{\tilde{y}}$ & $\pi \leq \gamma_{\text {rer }}$ & $\pi \leq \gamma_{i}$ \\
\hline Constant & -0.0037 & -0.1015 & -0.0043 & -0.0017 \\
& $(0.0055)$ & $(0.0723)$ & $(0.0028)$ & $(0.0013)$ \\
Inflation gap & $-0.6223^{*}$ & -0.0241 & -0.0398 & 0.0010 \\
& $(0.3358)$ & $(0.1561)$ & $(0.0513)$ & $(0.0394)$ \\
Output gap & 0.0287 & -0.4174 & -0.0004 & 0.0285 \\
& $(0.0423)$ & $(0.4510)$ & $(0.0296)$ & $(0.0192)$ \\
xrvol & -0.2798 & $0.8925^{* * *}$ & $0.3469^{*}$ & 0.0561 \\
& $(0.2013)$ & $(0.3654)$ & $(0.1850)$ & $(0.0388)$ \\
\hline Regime 2 & $\pi>\gamma_{\pi}$ & $\pi>\gamma_{\tilde{y}}$ & $\pi>\gamma_{r e r}$ & $\pi>\gamma_{i}$ \\
\hline Constant & -0.0017 & -0.0018 & $-0.0081^{* * *}$ & 0.0108 \\
& $(0.0017)$ & $(0.0013)$ & $(0.0025)$ & $(0.0241)$ \\
Inflation gap & -0.0092 & 0.0127 & 0.0953 & 0.0769 \\
& $(0.0507)$ & $(0.0408)$ & $(0.0614)$ & $(0.3934)$ \\
Output gap & 0.0144 & 0.0033 & 0.0442 & $-1.5579 * * *$ \\
& $(0.0232)$ & $(0.0250)$ & $(0.0251)$ & $(0.4988)$ \\
xrvol & $0.0781 * * *$ & $0.0617^{*}$ & $0.1028^{* * *}$ & -0.0552 \\
& $(0.0325)$ & $(0.0327)$ & $(0.0426)$ & $(0.0767)$ \\
\hline LM-test & 6.7515 & 7.1113 & 13.1572 & 7.1983 \\
Bootstrap P-Value & 0.686 & 0.606 & 0.049 & 0.589 \\
\hline \hline
\end{tabular}

Note:Values in paranthesis are standard errors. $* * *, * * *$ denote significance at $1 \%, 5 \%$ and $10 \%$ significance levels. 
Review of Economic Analysis 12 (2020) 167-202

Table B. 17: Structural regression model using GMM for Model 6

\begin{tabular}{|c|c|c|c|c|}
\hline Threshold variable & inflation gap & output gap & xrvol & interest rate \\
\hline Threshold estimate & 0.0119 & -0.0491 & 0.026103 & -0.01 \\
\hline 95\% C.I. & {$[-0.0089,0.0487]$} & {$[-0.05,0.0458]$} & {$[0.0094089,0.051331]$} & {$[-0.01,0.01]$} \\
\hline Regime 1 & $\pi \leq \gamma_{\pi}$ & $\pi \leq \gamma_{\tilde{y}}$ & $\pi \leq \gamma_{\text {rer }}$ & $\pi \leq \gamma_{i}$ \\
\hline \multirow[t]{2}{*}{ Constant } & 0.1694 & -0.0425 & $-0.4816 * *$ & $-1.1797 * * *$ \\
\hline & $(0.7389)$ & $(0.0745)$ & $(0.2109)$ & $(0.3228)$ \\
\hline \multirow[t]{2}{*}{ Inflation gap } & 0.7391 & 0.0133 & -0.1249 & 0.0217 \\
\hline & $(0.5263)$ & $(0.1241)$ & $(0.0819)$ & $(0.0405)$ \\
\hline \multirow[t]{2}{*}{ Output gap } & -0.1687 & $0.2761 * * *$ & 0.0522 & -0.0363 \\
\hline & $(0.1568)$ & $(0.1034)$ & $(0.0447)$ & $(0.0226)$ \\
\hline \multirow[t]{2}{*}{ xrvol } & -1.4086 & $0.4775^{*}$ & $-1.1974^{*}$ & -0.1984 \\
\hline & $(1.1642)$ & $(0.2926)$ & $(0.7335)$ & $(0.1788)$ \\
\hline Regime 2 & $\pi>\gamma_{\pi}$ & $\pi>\gamma_{\tilde{y}}$ & $\pi>\gamma_{\text {rer }}$ & $\pi>\gamma_{i}$ \\
\hline \multirow[t]{2}{*}{ Constant } & -0.1584 & 0.0434 & $0.5044 * *$ & $1.1568 * * *$ \\
\hline & $(0.7691)$ & $(0.0691)$ & $(0.2203)$ & $(0.321)$ \\
\hline \multirow[t]{2}{*}{ Inflation gap } & -0.0112 & $-0.1546^{*}$ & -0.0145 & $0.1047 *$ \\
\hline & $(0.6093)$ & $(0.0912)$ & $(0.1372)$ & $(0.0610)$ \\
\hline \multirow[t]{2}{*}{ Output gap } & $0.1623 * * *$ & 0.0477 & $0.1209 * * *$ & $-0.0835^{* *}$ \\
\hline & $(0.0553)$ & $(0.0844)$ & $(0.0456)$ & $(0.0366)$ \\
\hline \multirow[t]{2}{*}{ xrvol } & $0.3966^{*}$ & $0.3279 * *$ & -0.0928 & -0.047 \\
\hline & $(0.1520)$ & $(0.1502)$ & $(0.2142)$ & $(0.0792)$ \\
\hline \multicolumn{5}{|l|}{ Difference } \\
\hline \multirow[t]{2}{*}{ Constant } & 0.3279 & -0.0858 & $-0.986^{* *}$ & $-2.3365 * * *$ \\
\hline & $(1.5079)$ & $(0.1434)$ & $(0.4310)$ & $(0.6437)$ \\
\hline \multirow[t]{2}{*}{ Inflation gap } & $0.7503 * *$ & 0.1678 & -0.1104 & -0.0829 \\
\hline & $(0.3892)$ & $(0.1605)$ & $(0.1396)$ & $(0.0688)$ \\
\hline \multirow[t]{2}{*}{ Output gap } & -0.33100 & $0.2283 * *$ & -0.0687 & 0.0473 \\
\hline & $(0.1420)$ & $(0.1047)$ & $(0.0597)$ & $(0.0335)$ \\
\hline \multirow[t]{2}{*}{ xrvol } & -1.8052 & 0.1496 & -1.1046 & -0.1514 \\
\hline & (1.1337) & $(0.3246)$ & $(0.7466)$ & $(0.1666)$ \\
\hline \multirow[t]{2}{*}{ IMR(kappa) } & 0.1854 & -0.0637 & $-0.6303 * *$ & $-1.4569 * * *$ \\
\hline & $(0.9517)$ & $(0.0890)$ & $(0.2725)$ & $(0.4044)$ \\
\hline JSSE & 0.01408 & 0.015152 & 0.014503 & 0.0053781 \\
\hline JSTAT & 5.7658 & 5.3668 & 3.1158 & 5.7118 \\
\hline Upper regime $(\%)$ & $126 / 174$ & 156 & 69 & 127 \\
\hline
\end{tabular}

Note: The instrumental variables for the model are first and twelfth lags of inflation gap, output gap and real exchange rate. Values in paranthesis are standard errors. *,****** denote significance at $1 \%, 5 \%$ and $10 \%$ significance levels. 
DENIZ, STENGOS, YAZGAN Taylor Rule Model for Turkey

Table B. 18: Structural regression model using Least Squares for Model 6

\begin{tabular}{|c|c|c|c|c|}
\hline Threshold variable & inflation gap & output gap & xrvol & interest rate \\
\hline Threshold estimate & -0.002 & -0.0364 & 0.0272 & -0.01 \\
\hline $95 \%$ confidence interval & {$[-0.0089,0.0487]$} & {$[-0.05,0.0458]$} & {$[0.0094,0.0513]$} & {$[-0.01,0.01]$} \\
\hline Regime 1 & $\pi \leq \gamma_{\pi}$ & $\pi \leq \gamma_{\tilde{y}}$ & $\pi \leq \gamma_{\text {rer }}$ & $\pi \leq \gamma_{i}$ \\
\hline \multirow[t]{2}{*}{ Constant } & 0.0033 & $-0.0954 * * *$ & -0.2552 & $-0.8884 * * *$ \\
\hline & $(0.1180)$ & $(0.0373)$ & $(0.1629)$ & $(0.2437)$ \\
\hline \multirow[t]{2}{*}{ Inflation gap } & $-0.6168 * *$ & -0.0579 & $-0.091^{*}$ & 0.0036 \\
\hline & $(0.2997)$ & $(0.082)$ & $(0.0524)$ & $(0.0256)$ \\
\hline \multirow[t]{2}{*}{ Output gap } & 0.0291 & $0.1043^{*}$ & 0.0063 & -0.011 \\
\hline & $(0.0337)$ & $(0.0558)$ & $(0.0240)$ & $(0.0133)$ \\
\hline \multirow[t]{2}{*}{ xrvol } & -0.2794 & 0.1278 & $0.3038 *$ & -0.0135 \\
\hline & $(0.1847)$ & $(0.1182)$ & $(0.1643)$ & $(0.0578)$ \\
\hline Regime 2 & $\pi>\gamma_{\pi}$ & $\pi>\gamma_{\tilde{v}}$ & $\pi>\gamma_{\text {rer }}$ & $\pi>\gamma_{i}$ \\
\hline \multirow[t]{2}{*}{ Constant } & -0.0086 & $0.0949 * * *$ & 0.2465 & $0.8657 * * *$ \\
\hline & $(0.1166)$ & $(0.0353)$ & $(0.1646)$ & $(0.2404)$ \\
\hline \multirow[t]{2}{*}{ Inflation gap } & -0.0046 & 0.0282 & -0.0016 & 0.0342 \\
\hline & $(0.0859)$ & $(0.0471)$ & $(0.0803)$ & $(0.0296)$ \\
\hline \multirow[t]{2}{*}{ Output gap } & 0.0144 & -0.0255 & $0.0619 * *$ & -0.0251 \\
\hline & $(0.0199)$ & $(0.0291)$ & $(0.0276)$ & $(0.0173)$ \\
\hline \multirow[t]{2}{*}{ xrvol } & $0.0781 * * *$ & $0.0696 * * *$ & $0.1048 * * *$ & 0.0135 \\
\hline & $(0.0227)$ & $(0.0227)$ & $(0.0356)$ & $(0.0167)$ \\
\hline \multicolumn{5}{|l|}{ Difference } \\
\hline \multirow[t]{2}{*}{ Constant } & 0.0119 & $-0.1903 * * *$ & -0.5017 & $-1.7541 * * *$ \\
\hline & $(0.2345)$ & $(0.0724)$ & $(0.3275)$ & $(0.4841)$ \\
\hline \multirow[t]{2}{*}{ Inflation gap } & $-0.6122 * *$ & -0.0861 & -0.0894 & -0.0307 \\
\hline & $(0.2939)$ & $(0.0916)$ & $(0.0770)$ & $(0.0393)$ \\
\hline \multirow[t]{2}{*}{ Output gap } & 0.0146 & $0.1299 * *$ & -0.0556 & 0.0141 \\
\hline & $(0.0397)$ & $(0.0626)$ & $(0.0357)$ & $(0.0198)$ \\
\hline \multirow[t]{2}{*}{ xrvol } & $-0.3576 * *$ & 0.0582 & 0.1989 & -0.027 \\
\hline & $(0.1861)$ & $(0.1202)$ & $(0.1688)$ & $(0.0591)$ \\
\hline \multirow[t]{2}{*}{ IMR(kappa) } & 0.0087 & $-0.1263 * * *$ & -0.3174 & $-1.0893 * * *$ \\
\hline & $(0.1472)$ & $(0.0453)$ & $(0.2061)$ & $(0.3036)$ \\
\hline JSSE & 0.0154 & 0.0154 & 0.0148 & 0.0054 \\
\hline Upper regime (\%) & $145 / 174$ & 151 & 68 & 127 \\
\hline
\end{tabular}

Note: The instrumental variables for the model are first and twelfth lags of inflation gap, output gap and real exchange rate. Values in paranthesis are standard errors. $*, * *, * * *$ denote significance at $1 \%, 5 \%$ and $10 \%$ significance levels. 
Review of Economic Analysis 12 (2020) 167-202

\section{Model 7:}

$$
\begin{aligned}
& \Delta i_{t}=I\left(q_{t} \leq \gamma\right)\left(\beta_{0}^{L}+\beta_{1}^{L}\left(E_{t} \pi_{\text {end }}-\pi_{t}^{T}\right)+\beta_{2}^{L} \tilde{y}_{t}+\beta_{3}^{L} \text { rer }_{t}\right) \\
& +I\left(q_{t}>\gamma\right)\left(\beta_{0}^{H}+\beta_{1}^{H}\left(E_{t} \pi_{\text {end }}-\pi_{t}^{T}\right)+\beta_{2}^{H} \tilde{y}_{t}+\beta_{3}^{H} \operatorname{rer}_{t}\right)+u_{t} \quad \text { (B. 7) }
\end{aligned}
$$

Table B. 19: Hansen (2000) for Model 7

\begin{tabular}{lcccc}
\hline Threshold variable & inflation gap & output gap & rer & interest rate \\
\hline Threshold estimate & 0.0685 & -0.033 & 4.4526 & -0.010 \\
95\% C.I. & {$[-0.0141,0.0685]$} & {$[-0.1150,0.0630]$} & {$[4.4445,4.7258]$} & {$[-0.0100,-0.0100]$} \\
\hline Regime 1 & $\tilde{\pi}_{t} \leq \gamma_{\tilde{\pi}}$ & $\tilde{y}_{t} \leq \gamma_{\tilde{y}}$ & $r e r_{t} \leq \gamma_{\text {rer }}$ & $i_{t} \leq \gamma_{i}$ \\
\hline Constant & 0.0491 & $-0.2672^{*}$ & -0.2413 & 0.0210 \\
& $(0.0392)$ & $(0.1549)$ & $(1.2310)$ & $(0.0481)$ \\
Inflation gap & 0.0101 & 0.0443 & 0.2123 & 0.0065 \\
& $(0.0446)$ & $(0.0792)$ & $(0.4313)$ & $(0.0385)$ \\
Output gap & 0.0179 & $0.1147^{* *}$ & -1.3790 & 0.0043 \\
& $(0.0212)$ & $(0.0502)$ & $(1.0230)$ & $(0.0183)$ \\
RER & -0.0106 & $0.0586^{*}$ & 0.0547 & -0.0072 \\
& $(0.0083)$ & $(0.0330)$ & $(0.2776)$ & $(0.0102)$ \\
\hline Regime 2 & $\tilde{\pi}_{t}>\gamma_{\pi}$ & $\tilde{y}_{t}>\gamma_{\tilde{y}}$ & $r e r_{t}>\gamma_{\text {rer }}$ & $i_{t}>\gamma_{i}$ \\
\hline Constant & $0.4730^{* * *}$ & $0.0874^{* *}$ & 0.0642 & $0.0541^{* *}$ \\
& $(0.1688)$ & $(0.0388)$ & $(0.0409)$ & $(0.0258)$ \\
Inflation gap & -1.4130 & 0.0223 & 0.0038 & 0.0429 \\
& $(1.3080)$ & $(0.0457)$ & $(0.0382)$ & $(0.0300)$ \\
Output gap & 0.0942 & 0.0289 & 0.0282 & -0.0022 \\
& $(0.0582)$ & $(0.0332)$ & $(0.0190)$ & $(0.0160)$ \\
RER & $-0.0782^{* * *}$ & $-0.0189 * *$ & -0.0137 & $-0.0108^{* *}$ \\
& $(0.0255)$ & $(0.0082)$ & $(0.0087)$ & $(0.0054)$ \\
\hline LM-test & 8.9829 & 7.1104 & 8.3406 & $75.0088^{* * *}$ \\
Bootstrap P-Value & 0.3330 & 0.5870 & 0.4640 & 0.0000 \\
\hline \hline
\end{tabular}

Note:Values in paranthesis are standard errors. $* * *, * * *$ denote significance at $1 \%, 5 \%$ and $10 \%$ significance levels. 
DENIZ, STENGOS, YAZGAN Taylor Rule Model for Turkey

Table B. 20: Structural regression model using GMM for Model 7

\begin{tabular}{|c|c|c|c|c|}
\hline Threshold variable & inflation gap & output gap & rer & interest rate \\
\hline Threshold estimate & 0.0119 & -0.04 & 4.5193 & -0.01 \\
\hline $95 \%$ confidence interval & {$[-0.0089,0.0487]$} & {$[-0.05,0.05]$} & {$[4.5096,4.7878]$} & {$[-0.01,0.01]$} \\
\hline Regime 1 & $\tilde{\pi}_{t} \leq \gamma_{\tilde{\pi}}$ & $\tilde{y}_{t} \leq \gamma_{\tilde{y}}$ & $r e r_{t} \leq \gamma_{r e r}$ & $i_{t} \leq \gamma_{i}$ \\
\hline \multirow[t]{2}{*}{ Constant } & $1.2949^{* *}$ & $-0.3766^{* * *}$ & $1.6432 *$ & $-0.7468 * * *$ \\
\hline & $(0.6547)$ & $(0.1452)$ & $(0.9191)$ & $(0.2457)$ \\
\hline \multirow[t]{2}{*}{ Inflation gap } & $1.4229 * *$ & 0.1251 & $1.3813 * *$ & -0.0003 \\
\hline & $(0.6679)$ & $(0.1198)$ & $(0.7091)$ & $(0.0230)$ \\
\hline \multirow[t]{2}{*}{ Output gap } & -0.0246 & $0.1601 * * *$ & $-1.0021 *$ & -0.0166 \\
\hline & $(0.0667)$ & $(0.0531)$ & $(0.5491)$ & $(0.0214)$ \\
\hline \multirow[t]{2}{*}{ RER } & -0.0642 & $0.0719 * *$ & $-0.6174 * *$ & 0.0045 \\
\hline & $(0.0599)$ & $(0.0356)$ & $(0.2917)$ & $(0.0082)$ \\
\hline Regime 2 & $\tilde{\pi}_{t}>\gamma_{\pi}$ & $\tilde{y}_{t}>\gamma_{\tilde{y}}$ & $\operatorname{rer}_{t}>\gamma_{\text {rer }}$ & $i_{t}>\gamma_{i}$ \\
\hline \multirow{2}{*}{ Constant } & $-0.8267 *$ & $0.1632 * *$ & $5.0779 * * *$ & $0.7056 * * *$ \\
\hline & $(0.4582)$ & $(0.0710)$ & $(2.0504)$ & $(0.2043)$ \\
\hline \multirow[t]{2}{*}{ Inflation gap } & $0.7449 * *$ & 0.0201 & 0.0377 & $0.0526^{*}$ \\
\hline & $(0.3785)$ & $(0.0409)$ & $(0.0920)$ & $(0.0312)$ \\
\hline \multirow[t]{2}{*}{ Output gap } & $-0.2258 * * *$ & 0.0208 & $0.0789 *$ & -0.0315 \\
\hline & $(0.0798)$ & $(0.0742)$ & $(0.0456)$ & $(0.0227)$ \\
\hline \multirow[t]{2}{*}{ RER } & $-0.0392 * *$ & $-0.0245 * * *$ & $-0.8800 * * *$ & -0.0001 \\
\hline & $(0.0099)$ & $(0.0088)$ & $(0.3545)$ & $(0.0078)$ \\
\hline \multicolumn{5}{|l|}{ Difference } \\
\hline \multirow[t]{2}{*}{ Constant } & $2.1215^{* *}$ & $-0.5398 * * *$ & $-3.434 * * *$ & $-1.4524 * * *$ \\
\hline & (1.0922) & $(0.1541)$ & $(1.4470)$ & $(0.4475)$ \\
\hline \multirow[t]{2}{*}{ Inflation gap } & 0.6780 & 0.1050 & $1.3437 * *$ & -0.0529 \\
\hline & $(0.4565)$ & $(0.1283)$ & $(0.6948)$ & $(0.0386)$ \\
\hline \multirow[t]{2}{*}{ Output gap } & $-0.1703^{*}$ & $0.1393 *$ & $-1.0810 * *$ & 0.0149 \\
\hline & $(0.0899)$ & $(0.0818)$ & $(0.5519)$ & $(0.0273)$ \\
\hline \multirow[t]{2}{*}{ RER } & -0.0251 & $0.0965 * * *$ & $0.2626^{*}$ & 0.0046 \\
\hline & $(0.0591)$ & $(0.0373)$ & $(0.1552)$ & $(0.0099)$ \\
\hline \multirow[t]{2}{*}{ IMR(kappa) } & $1.2520 * *$ & -0.0643 & $-1.3721 * * *$ & $-0.8866 * * *$ \\
\hline & $(0.5765)$ & $(0.0834)$ & $(0.5602)$ & $(0.2824)$ \\
\hline JSSE & 0.0149 & 0.0153 & 0.0154 & 0.0057 \\
\hline J stat & 7.7312 & 7.7919 & 5.7484 & 2.4761 \\
\hline Upper regime $(\%)$ & $126 / 174$ & $151 / 174$ & $156 / 174$ & $127 / 174$ \\
\hline
\end{tabular}

Note: The instrumental variables for the model are first and twelfth lags of inflation gap,

output gap and real exchange rate.. Values in paranthesis are standard errors. *,*****

denote significance at $1 \%, 5 \%$ and $10 \%$ significance levels. 
Review of Economic Analysis 12 (2020) 167-202

Table B. 21: Structural threshold regression using Least Squares for Model 7

\begin{tabular}{|c|c|c|c|c|}
\hline Threshold variable & inflation rate & output gap & rer & interest rate \\
\hline Threshold estimate & 0.0119 & -0.04 & 4.7196 & -0.01 \\
\hline 95\% C.I. & {$[-0.0089,0.0487]$} & {$[-0.05,0.05]$} & {$[4.5096,4.7878]$} & {$[-0.01,0.01]$} \\
\hline Regime 1 & $\tilde{\pi}_{t} \leq \gamma_{\tilde{\pi}}$ & $\tilde{y}_{t} \leq \gamma_{\tilde{y}}$ & $r e r_{t} \leq \gamma_{\text {rer }}$ & $i_{t} \leq \gamma_{i}$ \\
\hline \multirow[t]{2}{*}{ Constant } & -0.1103 & $-0.2808 * *$ & $0.1853^{* *}$ & $-0.6731 * * *$ \\
\hline & $(0.1526)$ & $(0.1358)$ & $(0.0954)$ & $(0.2531)$ \\
\hline \multirow[t]{2}{*}{ Inflation gap } & -0.0958 & -0.0325 & 0.0055 & 0.0065 \\
\hline & $(0.1686)$ & $(0.0754)$ & $(0.0463)$ & $(0.0237)$ \\
\hline \multirow[t]{2}{*}{ Output gap } & -0.0021 & 0.0748 & 0.0285 & -0.0114 \\
\hline & $(0.0277)$ & $(0.0553)$ & $(0.0231)$ & $(0.0141)$ \\
\hline \multirow[t]{2}{*}{ RER } & $0.0434 * *$ & 0.0400 & $-0.0426^{*}$ & -0.0003 \\
\hline & $(0.0197)$ & $(0.0313)$ & $(0.0260)$ & $(0.0082)$ \\
\hline Regime 2 & $\tilde{\pi}_{t}>\gamma_{\pi}$ & $\tilde{y}_{t}>\gamma_{\tilde{y}}$ & rer $_{t}>\gamma_{\text {rer }}$ & $i_{t}>\gamma_{i}$ \\
\hline \multirow[t]{2}{*}{ Constant } & 0.0100 & $0.1870^{* * *}$ & 0.2382 & $0.6702 * * *$ \\
\hline & $(0.1336)$ & $(0.0626)$ & $(0.2010)$ & $(0.2199)$ \\
\hline \multirow[t]{2}{*}{ Inflation gap } & 0.0484 & 0.0267 & 0.0252 & $0.0456 *$ \\
\hline & $(0.0983)$ & $(0.0426)$ & $(0.0439)$ & $(0.0284)$ \\
\hline \multirow[t]{2}{*}{ Output gap } & $0.0556^{* *}$ & -0.0083 & -0.0153 & -0.0180 \\
\hline & $(0.0264)$ & $(0.0308)$ & $(0.0287)$ & $(0.0135)$ \\
\hline \multirow[t]{2}{*}{ RER } & $-0.0231 * * *$ & $-0.0198 * * *$ & -0.0474 & -0.0033 \\
\hline & $(0.0084)$ & $(0.0083)$ & $(0.0385)$ & $(0.0067)$ \\
\hline \multicolumn{5}{|l|}{ Difference } \\
\hline \multirow[t]{2}{*}{ Constant } & -0.1203 & $-0.4678 * * *$ & -0.0529 & $-1.3433 * * *$ \\
\hline & $(0.2688)$ & $(0.1467)$ & $(0.1770)$ & $(0.4709)$ \\
\hline \multirow[t]{2}{*}{ Inflation gap } & -0.1442 & -0.0592 & -0.0197 & -0.0390 \\
\hline & $(0.1520)$ & $(0.0847)$ & $(0.0640)$ & $(0.0370)$ \\
\hline \multirow[t]{2}{*}{ Output gap } & -0.0577 & 0.0831 & 0.0438 & 0.0065 \\
\hline & $(0.0387)$ & $(0.0600)$ & $(0.0368)$ & $(0.0190)$ \\
\hline \multirow[t]{2}{*}{ RER } & $0.0665 * * *$ & $0.0598 *$ & 0.0047 & 0.0029 \\
\hline & $(0.0217)$ & $(0.0319)$ & $(0.0360)$ & $(0.0097)$ \\
\hline \multirow[t]{2}{*}{ IMR(kappa) } & 0.1224 & $-0.1239 * *$ & -0.0152 & $-0.8230 * * *$ \\
\hline & $(0.1538)$ & $(0.0542)$ & $(0.0406)$ & $(0.2944)$ \\
\hline JSSE & 0.0157 & 0.0153 & 0.0155 & 0.0056 \\
\hline Upper regime (\%) & $126 / 174$ & $151 / 174$ & $57 / 174$ & $127 / 174$ \\
\hline
\end{tabular}

Note: The instrumental variables for the model are first and twelfth lags of inflation gap, output gap and real exchange rate. Values in paranthesis are standard errors. $*, * *, * * *$ denote significance at $1 \%, 5 \%$ and $10 \%$ significance levels. 